\title{
Kainate Receptor Gene Expression in the Developing Rat Brain
}

\author{
Sabine Bahn,' Benedikt Volk, ${ }^{2}$ and William Wisden' \\ ${ }^{1}$ MRC Laboratory of Molecular Biology, Neurobiology Division, Cambridge, CB2 2QH, United Kingdom and ${ }^{2}$ Department \\ of Neuropathology, University of Freiburg, Freiburg, Germany
}

Kainate-preferring receptors are a subclass of ionotropic glutamate receptors that might play a role in brain development. The expression of the five known genes encoding kainate receptor subunits (GluR-5, -6, -7, KA-1, and KA-2) was studied by in situ hybridization during pre- and postnatal development of the rat brain. We compared the combined expression patterns of these genes with autoradiography using ${ }^{3} \mathrm{H}-k$ ainate in the developing brain from embryonic day 12 (E12) through to adult. Although mRNAs for the receptor subunits (except KA-1) can be detected at stage E12, ${ }^{3} \mathrm{H}$ kainic acid binding (as an index of receptor protein) is not found at this stage. However, by E14 high-affinity kainate sites are found throughout the gray matter, but particularly in spinal cord, primordial cerebellum, and ventral forebrain structures. All genes undergo a peak in their expression in the late embryonic/early postnatal period. GluR-5 expression during development shows the most interesting features because the changes are qualitative. The GluR-5 gene shows peaks of expression around the period of birth in the sensory cortex (layers II, III, and IV), in CA1 hippocampal interneurons in the stratum oriens, in the septum, and in the thalamus. GluR-6 shows a prenatal expression peak in the cingulate gyrus of the neocortex. KA-1 transcripts appear with the development of the hippocampus and remain largely confined to discrete areas such as the CA3 region, the dentate gyrus, and subiculum. KA-2 transcripts are found throughout the CNS from as early as E12 and remain constant until adulthood. The GluR-5 and GluR- 6 genes are coexpressed in multiple peripheral ganglia (e.g., cranial nerve ganglia, dorsal root ganglia, and mural ganglia) at E14.

[Key words: glutamate receptor, kainate, development, in situ hybridization, sensory cortex, thalamus]

Excitatory amino acid (EAA) receptor activation is critical for fine-scale sculpting of neuronal circuitry during brain development (Mattson et al., 1988a,b; McDonald and Johnston, 1990). For example, ocular dominance plasticity (Kleinschmidt et al., 1987; Tsumoto et al., 1987; Carmignoto and Vicini, 1992),

\footnotetext{
Received Nov. 29, 1993; revised Feb. 21, 1994; accepted Mar. 2, 1994.

We thank Dr. Kerrie $\mathrm{I}$ homas for much useful practical advice regarding ligand autoradiography and cryostat sectioning, Stuart Ingham (Visual Aids Department, MRC Centre) for dedication in producing the figures, Theresa Langford for invaluable help in the supplying of material, and Drs. Stephen Hunt and Nige Unwin for general interest and support. This research was funded by a scholarship of the Studienstiftung des Deutschen Volkes (S.B.), a grant from the Freiburger Wissenschaftliche Gescllschaft (S.B.) and by the Medical Rescarch Council.

Correspondence should be addressed to W. Wisden, MRC Laboratory of Molecular Biology, Neurobiology Division, Hills Road, Cambridge, CB2 2QH, United Kingdom.
}

Copyright (C) 1994 Society for Neuroscience $0270-6474 / 94 / 145525-23 \$ 05.00 / 0$ development of barrel fields in the sensory cortex (Schlaggar et al., 1993), stratification of dendrites in the developing retina (Bodnarenko and Chalupa, 1993), and the induction of some forms of neuronal differentiation (Kalb and Hockfield, 1990) all require EAA receptor activity. EAAs have trophic effects on neurons (Pearce et al., 1987; Balázs et al., 1988; Hack et al., 1993; Pizzi et al., 1994; reviewed by Gould and McEwen, 1993), are required for neuronal migration (Komuro and Rakic, 1993), and may regulate neuronal numbers during development by contributing to cell death via excitotoxicity (Cox et al., 1990; Mentis et al., 1993; Mount et al., 1993; O’Donoghue et al., 1993).

These developmental effects are mediated directly and indirectly by the same classes of receptors that are used for excitatory communication and the generation of plasticity in the adult brain, namely, AMPA/low-affinity kainate (AMPA-preferring), high-affinity kainate (kainate-preferring), NMDA-gated channels and metabotropic receptors (reviewed by Young and Fagg, 1990; Monaghan and Anderson, 1991; Gasic and Hollmann, 1992; Nakanishi, 1992; Monaghan, 1993; Wisden and Seeburg 1993a,b). Kainate-preferring receptors can be constructed from subunits GluR-5, GluR-6, GluR-7, KA-1, and KA-2/ $\gamma 2$ (Bettler et al., 1990, 1992; Egebjerg et al., 1991; Werner et al., 1991; Herb et al., 1992; Lomeli et al., 1992; Sakimura et al., 1992; Sommer et al., 1992; Partin et al., 1993; Wenthold et al., 1993; reviewed Wisden and Seeburg, 1993a,b). They can be generated in vitro from recombinant homomeric (GluR-5 and GluR-6) or heteromeric configurations (e.g., KA-2/GluR-6), and form channels with rapidly desensitizing responses to kainate (Herb et al., 1992; Sakimura et al., 1992; Sommer et al., 1992), and can further be distinguished from AMPA receptors because their desensitization rate can be modulated by ConA but not cyclothiozide (Partin et al., 1993). These kainate-gated channels are probably physiologically modulatable at the synapse by cAMP dependent phosphorylation (Raymond et al., 1993; Wang et al., 1993). The native agonist is presumed to be glutamate.

Since the expression of high-affinity kainate binding sites is markedly transient in some brain regions (Miller et al., 1990; Garcia-Ladona and Gombos, 1993), it is possible that kainate receptors are involved in some aspects of EAA dependent neuronal development outlined above. A marked peak in expression of high-affinity ${ }^{3} \mathrm{H}$-kainate binding sites occurs in the hippocampus and neocortex in the first 2 weeks after birth coinciding with periods of synaptogenesis (Miller et al., 1990; Garcia-Ladona and Gombos, 1993), and the deep cerebellar nuclei, inferior olive nucleus, pontine nuclei, inferior colliculi, and stratum oriens of CAl have high numbers of sites around birth, with very little binding detectable in the adult (Garcia-Ladona and Gombos, 1993). A peak of gene expression of a kainate- 
selective ionotropic subunit similarly takes place in Drosophila during a major period of CNS neurogenesis (Ultsch et al., 1992). The occurrence of such phenomena across large distances of evolution might suggest a fundamental importance of kainate receptors in development.

Here, we examine the distribution of high-affinity kainate receptor subunit transcripts in the developing rat brain. In certain areas of the brain the composition of the five receptor subunits during embryonic and early postnatal development differ substantially from those in the adult. Although Bettler et al. (1990) first drew attention to the regulated expression of GluR-5 in the developing mouse brain, there are no systematic comparisons available with other related subunits. Further, we observed several striking features of GluR-5 expression in the developing rat brain not previously reported for the mouse.

\section{Materials and Methods}

Animals. Brains were taken from Sprague-Dawley rats using animals from embryonic ages E12, E14, E17, E19; postnatal ages P0, P5, P12; and adult males (150-180 d). Sex determination was only performed on adult rats. The occurrence of a vaginal plug was defined as E0, and the day of birth as P0. Uteri of pregnant females were rinsed and the embryos dissected out in ice-cold HEPES buffer (Laurie and Schrotz, 1994). The embryos/brains were frozen on dry ice and $14 \mu \mathrm{m}$ sections were cut on a cryostat and thaw mounted onto poly-L-lysine-coated slides. After briefly fixing in $4 \%$ (w/v) paraformaldehyde, sections were stored in $95 \%$ ethanol at $4^{\circ} \mathrm{C}$ (Wisden and Morris, 1994).

In situ hybridization. For each high-affinity kainate receptor subunit gene (GluR-5, GluR-6, GluR-7, KA-1, KA-2), unique 45-base antisense oligonucleotides were used. The oligonucleotide sequences and experimental procedures (labeling, hybridization, posthybridization washing) were exactly as described previously (Wisden and Seeburg, 1993b; Wisden and Morris, 1994). Probes were 3 ' end-labeled using terminal deoxynucleotidyl transferase (Boehringer-Mannheim) and a 30:1 molar ratio of $\alpha^{35} \mathrm{~S}$-dATP $(1200 \mathrm{Ci} / \mathrm{mmol}$; New England Nuclear). In situ hybridization was performed on sagittal sections of whole embryos of E12 and E14 and on horizontal sections of brains taken of embryonic stages E17 and $\mathrm{E} 19$, as well as postnatal ages $\mathrm{P} 0, \mathrm{P} 7$, and P14 and from adults.

In order to confirm developmental changes, two sections from each of three animals at each age were hybridized and examined for each probe. After hybridization and washing, sections were exposed to Kodak XAR-5 film and dipped in photographic emulsion (Ilford K5). Anatomy of autoradiographs and thionin-stained sections was determined using the atlases of Paxinos and Watson (1986), Paxinos et al. (1991), and Kaufman (1992). Microscopic examination of emulsion-coated sections was performed for every described structure in order to confirm the cellular locations reported.

Signal specificity was assessed by competition experiments in which radiolabeled probes were hybridized to sections in the presence of excess (100-fold) unlabeled probe. This resulted virtually in blank autoradiographs, except for some nonspecific labeling of peripheral tissues. The assessment of the specificity of the probes has been described previously (Wisden and Seeburg, 1993b). Table 1 is designed to be a summary of the text and figures and does not reflect an accurate quantitative determination of mRNA copies/cell. The assignments $(+)$ to +++ were made by two of the authors individually rating autoradiographic signal intensity using the original $\mathrm{x}$-ray films and emulsion data for each of the areas mentioned in the table. These results were then pooled to produce a consensus. "Weakly detectable $(+)$ " is distinguished from "undetectable" on the basis of comparing the autoradiographic signal with labeled probe alone to that of the same probe incubated with an excess of cold oligonucleotide for a given exposure time.

Kainate receptor autoradiography. Autoradiography with ${ }^{3} \mathrm{H}$-kainic acid was performed as described previously (Monaghan and Cotman, 1982; Monaghan, 1993). Tissue slices were thaw mounted onto gelatinecoated slides and dried at room temperature. They were then desiccated at $-20^{\circ} \mathrm{C}$ until use. After warming to room temperature, the slides were preincubated for $1 \mathrm{hr}$ in freshly made $50 \mathrm{~mm}$ Tris-citrate buffer ( $\mathrm{pH}$ 7.1) at $0^{\circ} \mathrm{C}$ and then incubated with $15 \mathrm{nM}{ }^{3} \mathrm{H}$-kainic acid $(50 \mathrm{Ci} / \mathrm{mmol}$; New England Nuclear-Du Pont) in the same buffer at $0^{\circ} \mathrm{C}$ for $30 \mathrm{~min}$. All slides were subsequently rinsed in ice-cold buffer and finally in ice- cold deionized water. Sections were rapidly dried under a stream of cold air and exposed to tritium-sensitive film (Hyperfilm, Amersham) for 3 weeks. In order to define nonspecific binding, adjacent sections were incubated with $50 \mu \mathrm{M}$ unlabeled kainic acid (Tocris Neuramin), in addition to the labeled ligand.

\section{Results}

During the development of the rat brain, a specific expression pattern was found for each of the five high-affinity kainate receptor subunit genes. These patterns changed during development. The total results are summarized in Table 1.

\section{Kainic acid binding in development}

To enable a useful side-by-side comparison and orientation with our in situ hybridization studies, we replicated the ${ }^{3} \mathrm{H}$-kainate binding studies of Miller et al. (1990) on parallel sections, except that these authors did not report embryonic binding sites. Although the mRNA for most of the receptors (except KA-1) can be detected at stage E12 in for example dorsal root ganglia (GluR-6), spinal cord (GluR-5, -6, KA-2) (Fig. 3), ${ }^{3} \mathrm{H}$-kainic acid binding (as an index of receptor protein) is not detectable until E14 (Figs. 1, 2). However, by E14 high-affinity kainate sites are found throughout the gray matter, but particularly in the spinal cord, primordial cerebellum, and in forebrain structures such as the striatum (Fig. 2). No specific binding is detectable in non-neuronal tissue of whole embryo sections. At E17, kainate sites are prevalent throughout the cortex, septum, hippocampus, and thalamus (Fig. 2).

The thalamus showed a very strong transient expression of kainic acid binding sites. At 2 weeks after birth and in the adult (Monaghan and Cotman, 1982; Unnerstall and Wamsley, 1983), only the reticular thalamic nucleus markedly expresses kainate sites (Fig. 1), yet at E19, P0, and P5, most thalamic nuclei are strongly labeled (Fig. 1). For example, at P5 both the medial geniculate and lateral geniculate nuclei are rich sources of sites compared to the same structures in the adult (Fig. 1). Miller et al. (1990) rcport that the laterodorsal thalamic nuclei also exhibit exuberant binding sites a day after birth with a strong decline in the number of sites found in the adult.

A clear developmental change is also seen in the hippocampus (Figs. 1, 2). At E17 diffuse kainate binding is present over the developing hippocampus, with the whole structure strongly labelled at E19 (Fig. 2). The characteristic pattern of kainate binding in the adult hippocampus is strong binding in the CA3 sector with relatively few sites in CAl (Foster et al., 1981; Monaghan and Cotman, 1982; Monaghan et al., 1986; Unnerstall and Wamsley, 1983; Represa et al., 1987). However, in the late embryonic and early postnatal period, there is marked binding over the CA1 (stratum oriens) region (Fig. 1) that diminishes by P14. A similar observation was noted for the mouse (GarciaLadona and Gombos, 1993).

\section{Kainate receptor gene expression in developing cortex}

At E14, the cortex consists of a primordial plexiform layer that is split before $\mathrm{E} 12$ by the cortical plate of postmitotic neuroblasts (reviewed by Jacobson, 1991). The E14 telencephalon already has moderate amounts of KA-2 mRNA, but no expression for the other subunit mRNAs is seen (Fig. 4). By E17 and E19, GluR-5, GluR-6, and GluR-7 are the most abundantly expressed genes in the outer cortical layer (Figs. 5, 6). The KA-2 transcripts are found in both outer and inner (subplate) layers. Only KA-2 is expressed in the cortical plate at E12 and El4 (Fig. 4). 
Table 1. Summary of developmental changes of kainate receptor gene expression during rat brain development (see Materials and Methods): Expression of subunit mRNAs for high-affinity kainate receptors during rat ontogeny

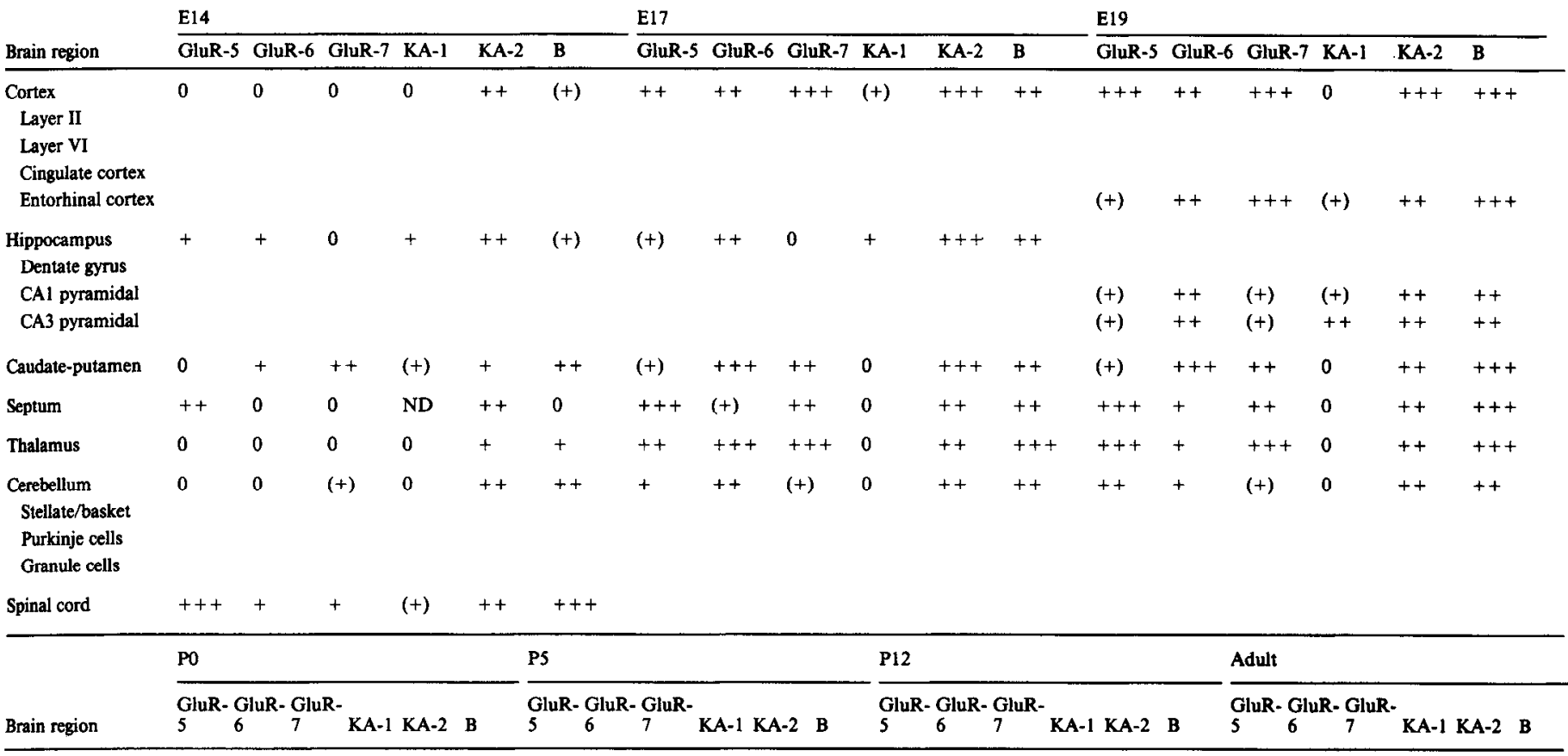

Cortex

\begin{tabular}{|c|c|c|c|c|c|c|c|c|c|c|c|c|c|c|c|c|c|c|c|c|c|c|c|c|}
\hline Layer II & +++ & + & $(+)$ & $(+)$ & +++ & +++ & +++ & $(+)$ & + & + & +++ & ++ & ++ & $(+)$ & + & $(+)$ & +++ & ++ & + & $(+)$ & + & $(+)$ & +++ & ++ \\
\hline Layer VI & + & $(+)$ & +++ & $(+)$ & ++ & +++ & + & $(+)$ & +++ & $(+)$ & +++ & ++ & + & $(+)$ & +++ & $(+)$ & +++ & +++ & $(+)$ & $(+)$ & ++ & $(+)$ & +++ & ++ \\
\hline Cingulate cortex & ++ & +++ & ++ & $(+)$ & ++ & +++ & ++ & ++ & +++ & + & +++ & +++ & ++ & ++ & +++ & 0 & +++ & +++ & + & ++ & ++ & 0 & +++ & ++ \\
\hline Entorhinal cortex & ++ & ++ & +++ & $(+)$ & +++ & +++ & + & + & +++ & $(+)$ & +++ & ++ & ++ & + & +++ & 0 & +++ & ++ & + & + & ++ & 0 & +++ & ++ \\
\hline \multicolumn{25}{|l|}{ Hippocampus } \\
\hline Dentate gyrus & $(+)$ & ++ & + & + & +++ & +++ & + & + & +++ & + & +++ & +++ & + & ++ & ++ & + & +++ & + & + & +++ & + & + & +++ & ++ \\
\hline CAl pyramidal & ++ & ++ & + & $(+)$ & +++ & +++ & ++ & + & + & $(+)$ & +++ & $(+)$ & ++ & + & + & $(+)$ & +++ & $(+)$ & + & + & $(+)$ & $(+)$ & +++ & $(+)$ \\
\hline CA3 pyramidal & + & ++ & $(+)$ & +++ & +++ & +++ & + & + & 0 & +++ & +++ & +++ & + & ++ & 0 & +++ & +++ & +++ & $(+)$ & +++ & 0 & +++ & +++ & +++ \\
\hline Caudate-putamen & $(+)$ & +++ & + & 0 & +++ & +++ & 0 & + & ++ & 0 & +++ & +++ & 0 & + & + & 0 & +++ & +++ & 0 & ++ & + & 0 & +++ & ++ \\
\hline Septum & +++ & 0 & + & 0 & ++ & ++ & ++ & 0 & + & 0 & +++ & +++ & ++ & 0 & + & 0 & ++ & ++ & + & 0 & + & 0 & ++ & + \\
\hline Thalamus & +++ & + & ++ & 0 & ++ & +++ & +++ & 0 & + & 0 & ++ & +++ & +++ & $(+)$ & + & 0 & ++ & + & + & 0 & + & 0 & ++ & $(+)$ \\
\hline Cerehellum & & & & & & +++ & & & & & & & & & & & & & & & & & & 0 \\
\hline Stellate/basket & 0 & 0 & + & 0 & 0 & & 0 & 0 & ++ & 0 & 0 & + & 0 & 0 & ++ & 0 & 0 & + & 0 & 0 & $+t$ & 0 & 0 & ++ \\
\hline Purkinje cells & ++ & 0 & 0 & 0 & 0 & & ++ & 0 & 0 & $(+)$ & 0 & & +++ & 0 & 0 & $(+)$ & 0 & & +++ & 0 & 0 & + & 0 & \\
\hline Granule cells & $(+)$ & +++ & 0 & 0 & ++ & & $(+)$ & +++ & 0 & 0 & +++ & +++ & $(+)$ & +++ & 0 & 0 & +++ & +++ & 0 & +++ & 0 & 0 & +++ & +++ \\
\hline
\end{tabular}

0 , not detectable; $(+)$ weakly detectable; + , detectable; ++ , moderate; +++ , abundant. $B,{ }^{3} \mathrm{H}$-kainic acid autoradiography.

Cortical GluR-5 expression during development shows the most interesting features (Fig. 11). Unlike the other subunit genes, for any given age GluR-5 subunit gene expression varies depending on the region of the neocortex examined. In particular, the somatosensory cortex expresses more GluR-5 transcript than other cortical areas in the same horizontal section.
Transcripts are predominantly observed in the outer layers of the sensory cortex. A very obvious peak occurs for GluR-5 gene expression around birth in this region. The expression is especially high in layer II/III of the cortex (lamina granularis externa), where on the $\mathrm{x}$-ray film the positive signal appears as a very dense, bright band (Fig. 11). Emulsion autoradiography

Figure 1. Complete developmental ${ }^{3} \mathrm{H}$-kainic acid binding profile to sagittal $(E 12, E 14)$ and horizontal (all others) sections from rats. The $E 17$ and $E 19$ sections are horizontal sections through the whole head including the skull and snout. Representative sections for total binding are shown, nonspecific binding (i.e., binding in the presence of an excess of unlabeled kainic acid) was not above film background. Note the increase in binding in $E 19$ and $P O$ sections. No binding was detectable at E12. All images are printed to the same scale, reflecting the increase in brain size with development. See Appendix for abbreviations. Scale bar, $2 \mathrm{~mm}$.

Figure 2. Enlargement of ${ }^{3} \mathrm{H}$-kainic acid binding autoradiographs at E14 (sagittal section), E17, and E19 (horizontal sections through the whole head). The corresponding Nissl stains for each of the autoradiographs are illustrated to the right. the ventricular zone (VZ) is unlabeled. See Appendix for abbreviations. Scale bar, $0.8 \mathrm{~mm}$. 

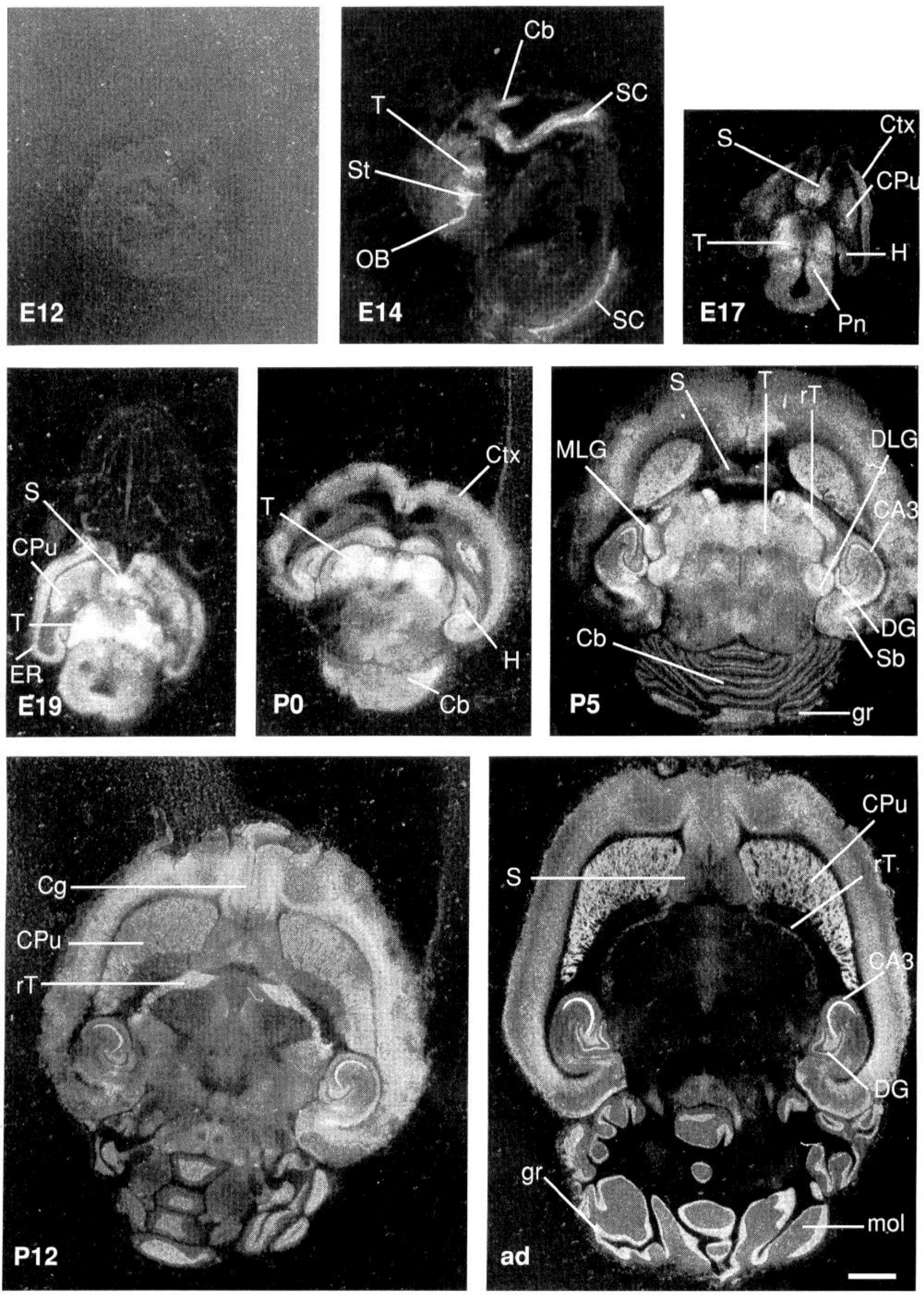

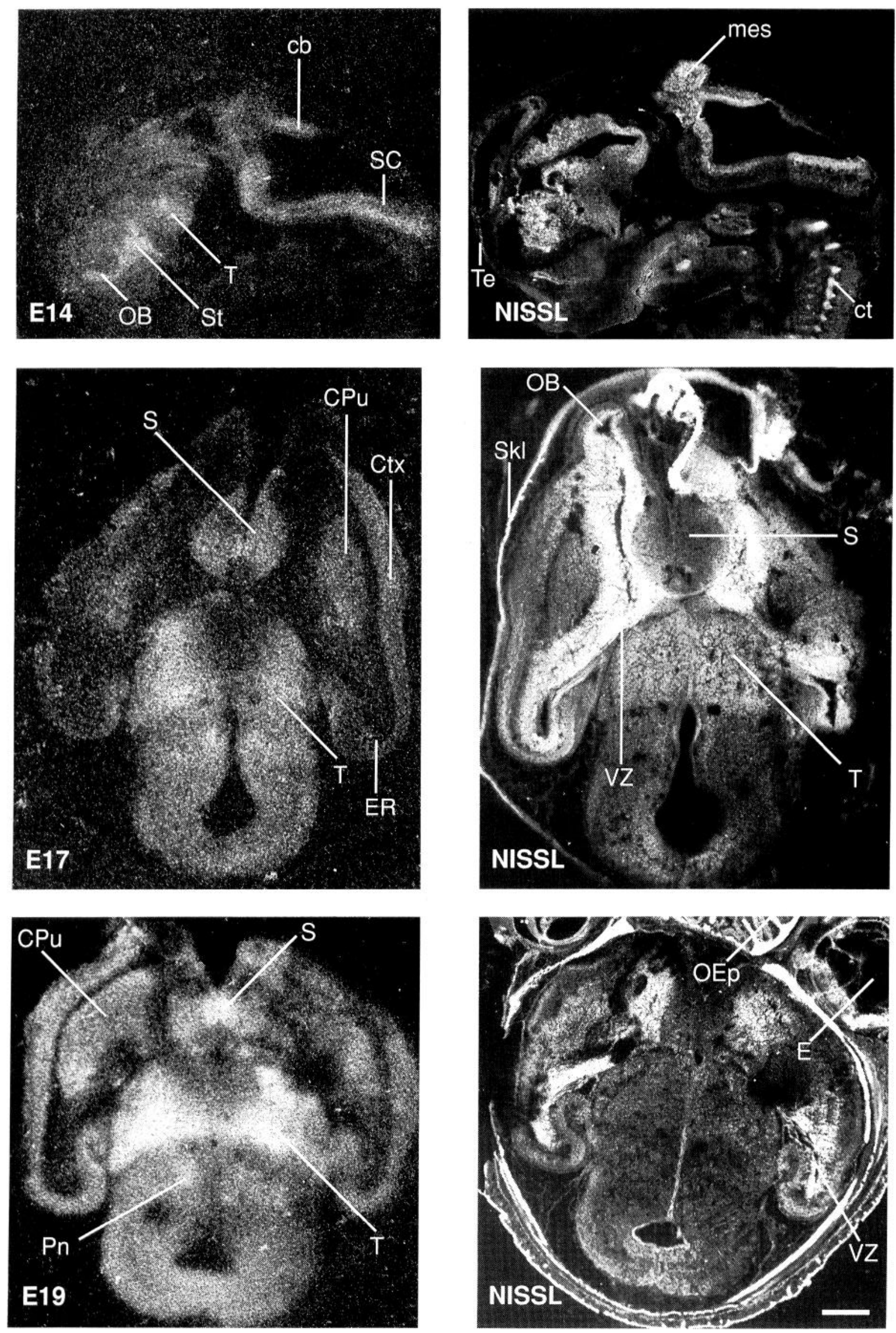

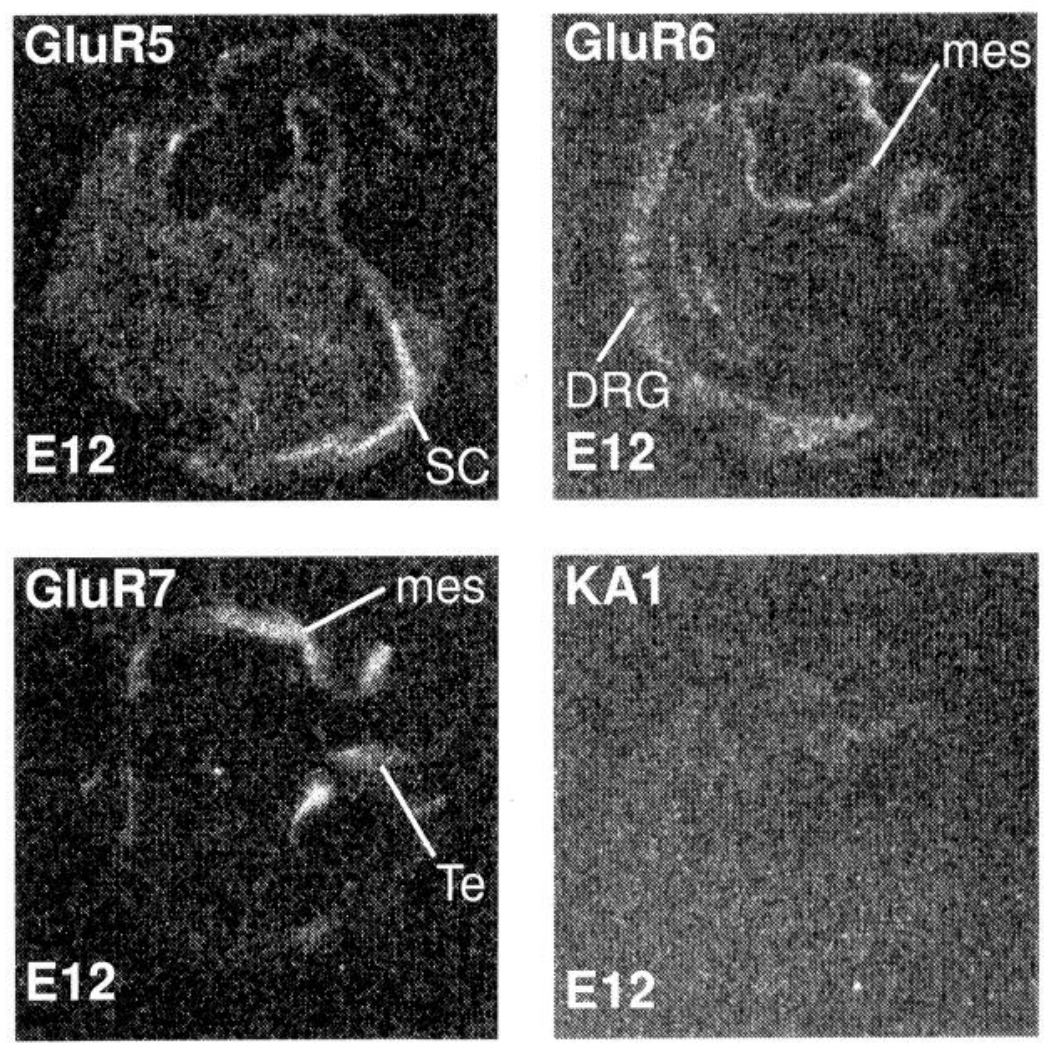

Figure 3. X-ray film autoradiographs illustrating distribution of kainate-preferring receptor subunit mRNAs encoding GluR-5, -6, -7, KA-1, and KA-2 subunits in sagittal sections of E12 rat embryos. GluR-6 mRNA is present in dorsal root ganglia. No KA-1 signal is detectable at E12. The bottom right panel shows a Nissl (thionin) stain of the whole embryo section. See Appendix for abbreviations. Scale bar, 1.75 $\mathrm{mm}$.
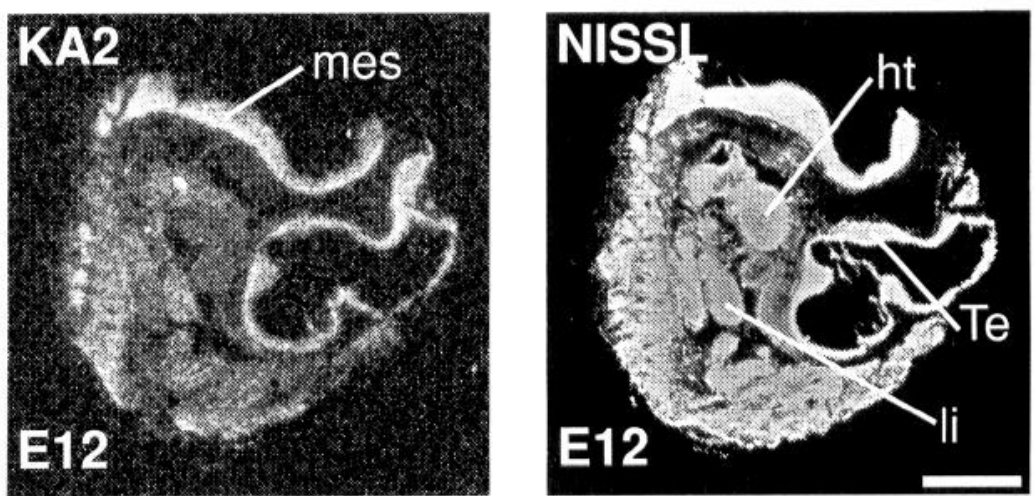

confirms that this cell dense layer of the E19 cortex (layer II/ III) has a high accumulation of silver grains after being hybridized with the GluR-5 probe (Fig. 12). Cells more interior or exterior to this layer are unlabelled (Fig 12). By P12, this layer II/III band is diminished in intensity for the GluR-5 signal and has vanished in the adult (Fig. 12). In contrast, the KA-2 gene is expressed in very many cells of the E19 cortex, regardless of their laminar position (Fig. 13) and continues to be expressed in many cortical neurons of the adult.

As the width of the neocortex increases between E19 and P5 a further population of GluR-5-expressing cells becomes apparent. The area around layer IV is heavily labeled in a more punctate fashion at P0, P5, and P12 (Fig. 11). Although the majority of cells are unlabeled, a small number of cells express the GluR-5 gene at high levels (Fig. 12e,f, arrowheads). This population of GluR-5-expressing cells is transient or expresses the gene transiently, since examination of the corresponding region in the adult reveals little or no expression (Fig. 12g,h). Again in contrast to the regulated expression of GluR-5, the KA-2 transcripts are found in these cell layers in an invariant manner throughout development (Fig. 13).

The hybridization signal for GluR-6 in the cortex is generally low; but in the cingulate cortex this subunit is very prominent, especially at age P0 (Fig. 7), where it undergoes a clear peak in expression. In contrast to GluR-6, the GluR-7 gene is rather abundant in the inner cortical layers. However, the qualitative

Figure 4. X-ray film autoradiographs illustrating distribution of kainate-preferring receptor subunit mRNAs encoding GluR-5, -6, -7, KA-1, and KA-2 subunits in sagittal sections of E14 rat embryos. GluR-5 and -6 are colocalized in some peripheral ganglia (e.g., the MG ganglion). GluR-7 and KA-2 are the only genes expressed in the striatum at this age. Nissl (thionin) stain of whole embryo section is shown in the bottom right panel. See Appendix for abbreviations. Scale bar, $1.6 \mathrm{~mm}$. 

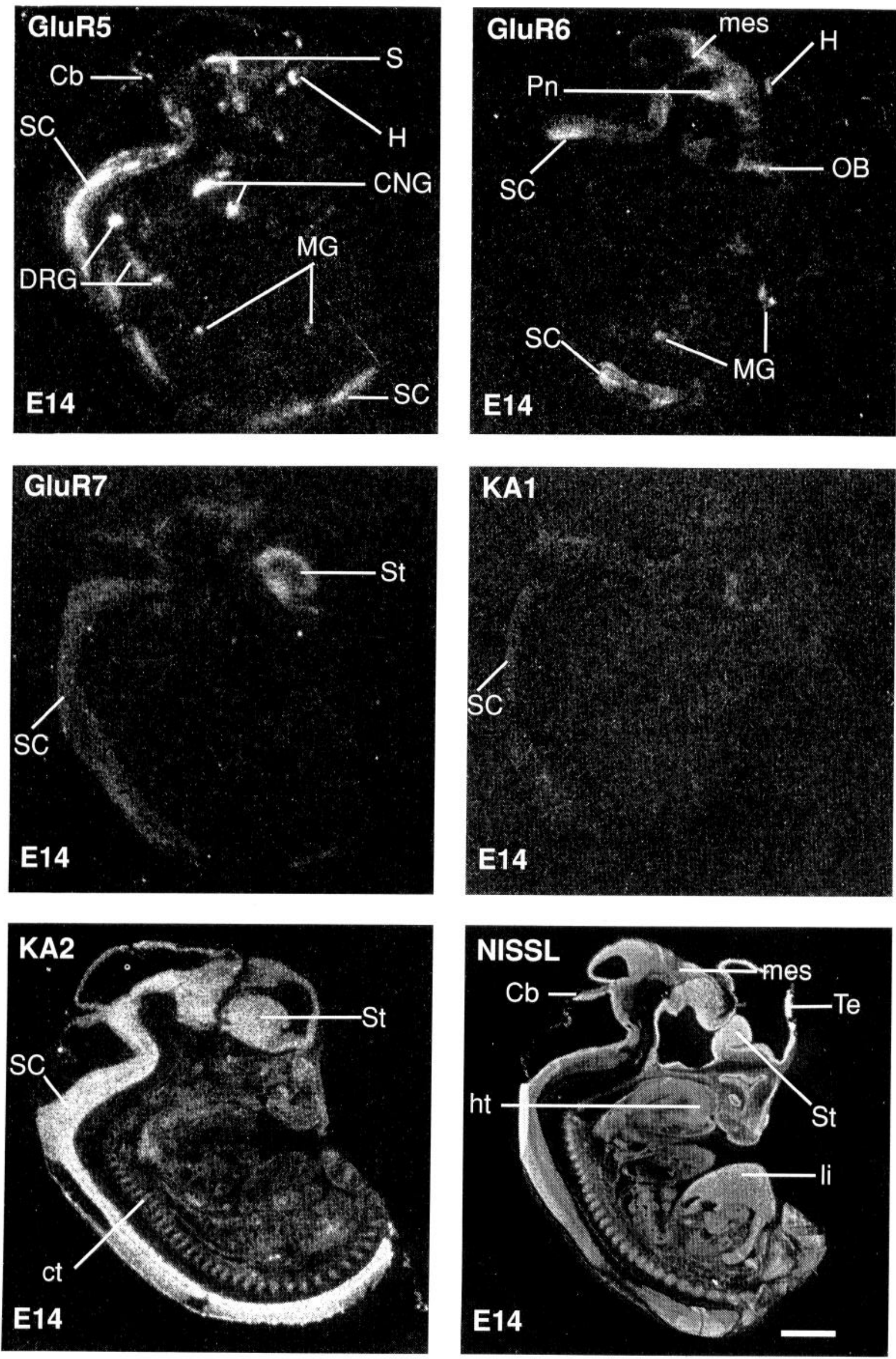

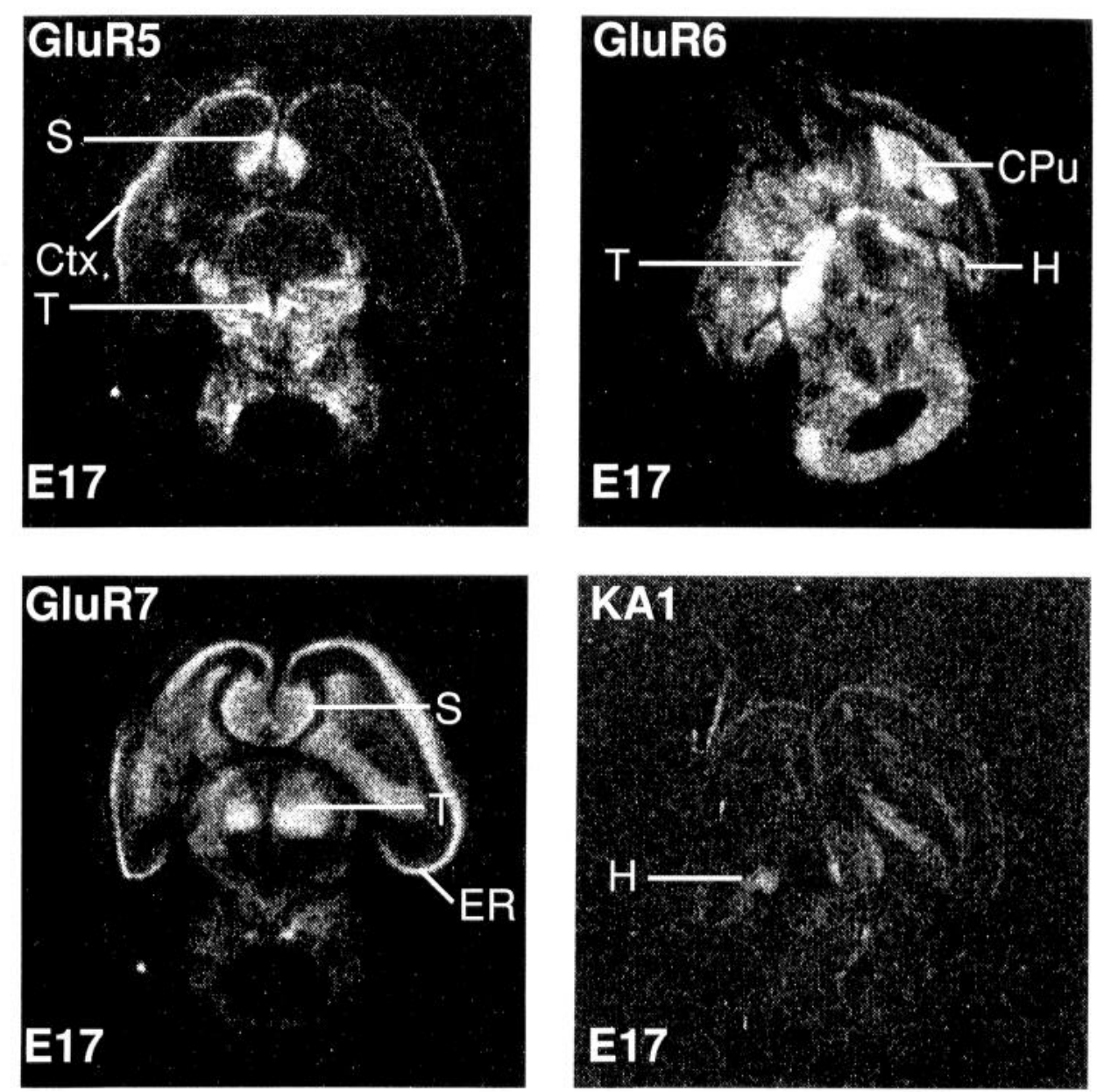

Figure 5. X-ray film autoradiographs illustrating distribution of kainate-preferring receptor subunit mRNAs encoding GluR-5, -6, -7, KA-1, and KA-2 subunits in horizontal sections of E17 rat embryo heads. Nissl (thionin) stain of the whole embryo head is shown in the bottom right panel. See Appendix for abbreviations. Scale bar, $1.4 \mathrm{~mm}$.
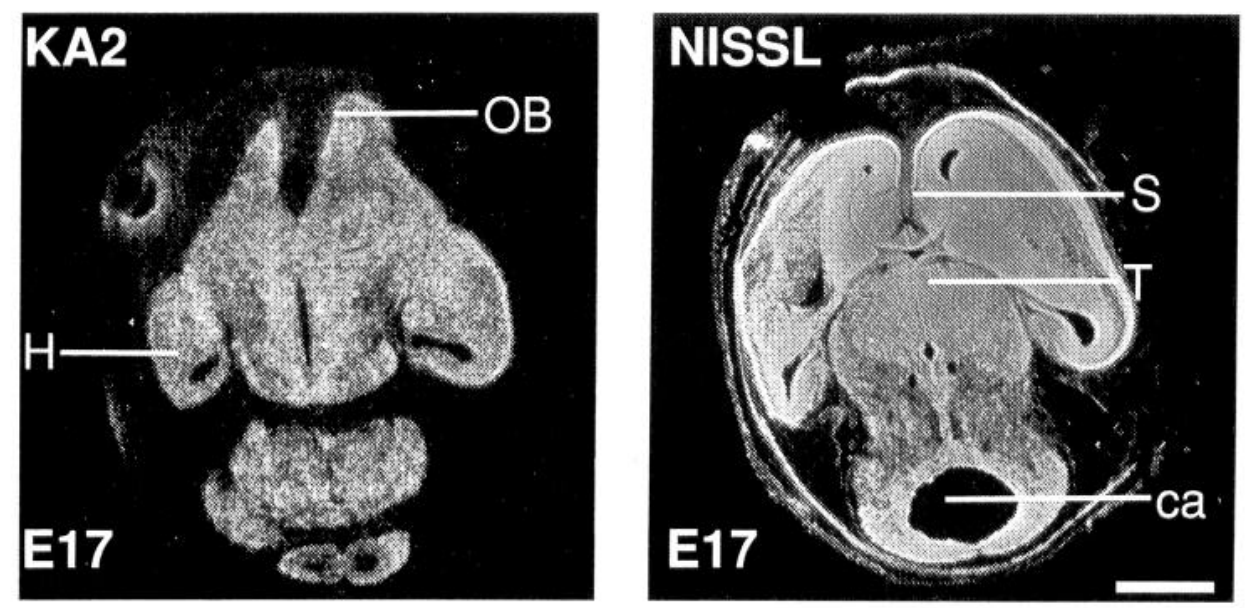

expression of GluR-7 during ontogeny does not seem to change remarkably, although it also shows a perinatal expression peak (E19, P0, and P5; see Table 1).

The ${ }^{3} \mathrm{H}$-kainic acid binding in the developing cortex might correlate especially with the expression of GluR-6 (gyrus cingli), GluR-7 (inner cortical layers, entorhinal cortex) and KA-2. Perinatally the binding is diffuse without restriction to any layer. There is no obvious accumulation of ${ }^{3} \mathrm{H}$-kainate binding sites corresponding to GluR-5 in the somatosensory cortex.
Kainate receptors in the developing hippocampus

The formation of the hippocampal structures begins around E14 (Stanfield and Cowan, 1988), and kainate receptor subunit gene expression also begins around this age. However, the signals are very faint (Fig. 4). The dentate granule cells are largely born postnatally (reviewed Gould and McEwen, 1993). The compliment of kainate receptor subunits transcripts found in these dentate granule cells in the early postnatal period is essentially 

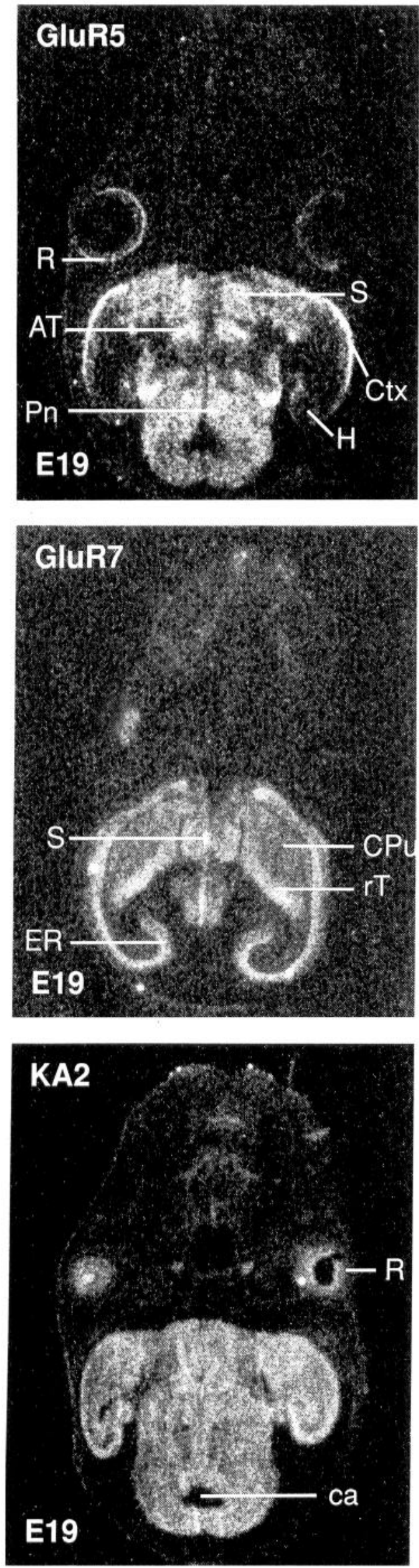
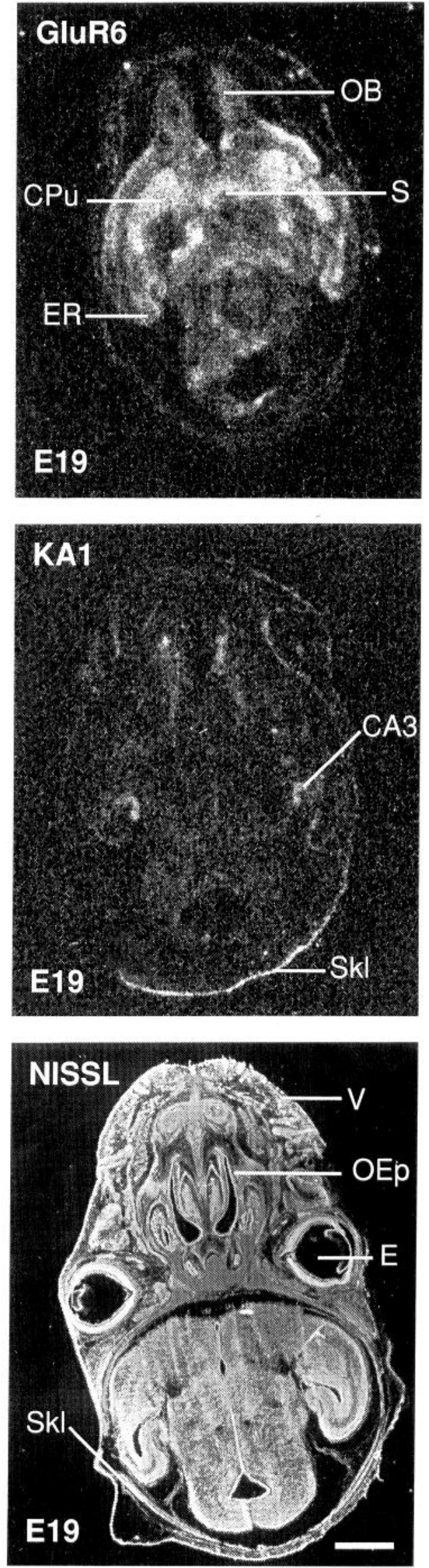

Figure 6. X-ray film autoradiographs illustrating distribution of kainate-preferring receptor subunit mRNAs encoding GluR-5, -6, -7, KA-1, and KA-2 subunits in horizontal sections through the skull of E19 rat embryos. Note that specific GluR-5, -7, and KA-2 expression can be seen in the retina. Nissl (thionin) stain of the whole embryo head is shown in the bottom right panel. See Appendix for abbreviations. Scale bar, $1.5 \mathrm{~mm}$. 

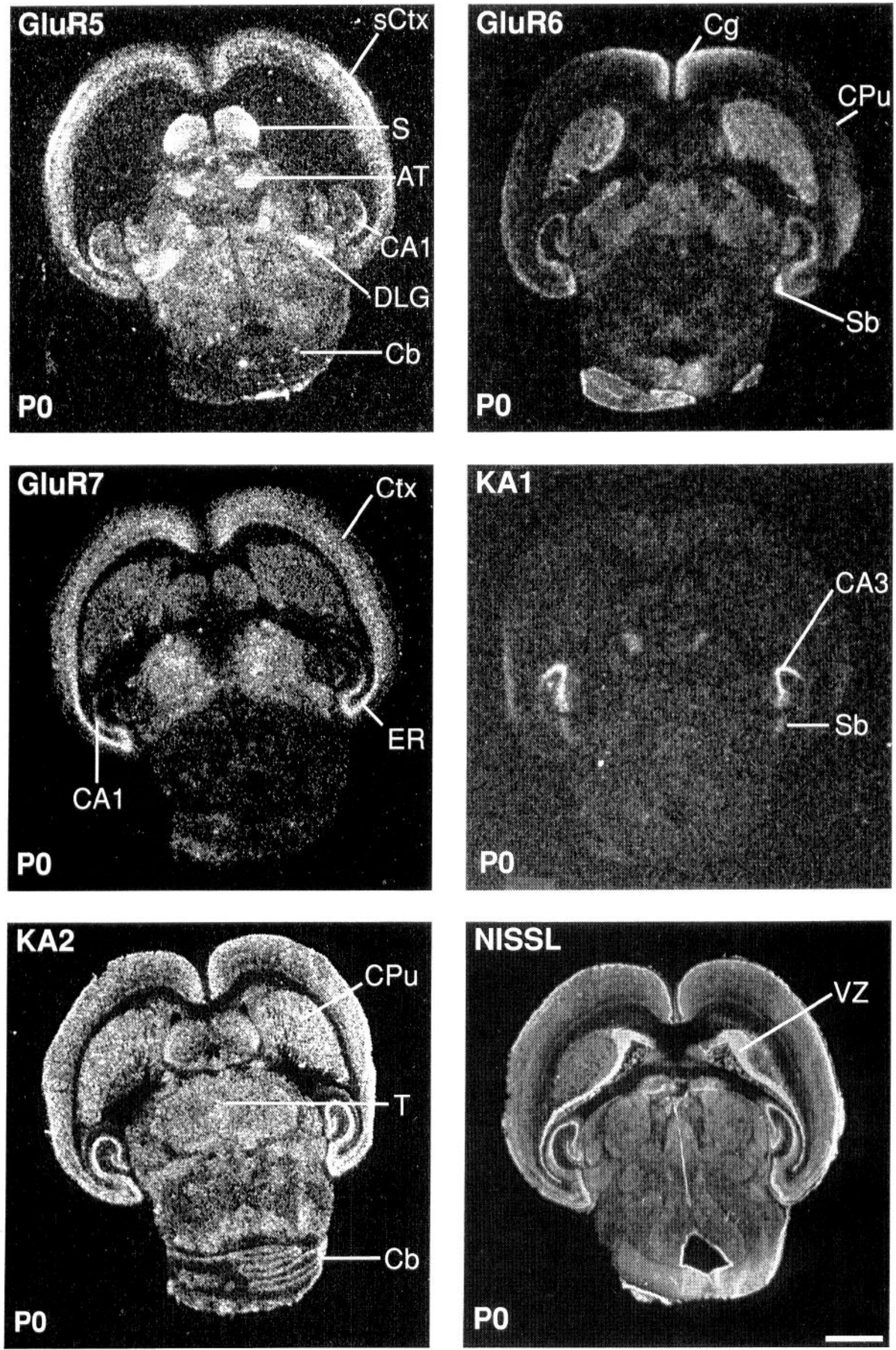

Figure 7. X-ray film autoradiographs illustrating distribution of kainate-preferring receptor subunit mRNAs encoding GluR-5, -6, -7, KA-1, and KA-2 subunits in horizontal sections of P0 rat brains. Nissl (thionin) stain of a corresponding section is shown in the bottom right panel. See Appendix for abbreviations. Scale bar, $1.7 \mathrm{~mm}$. 

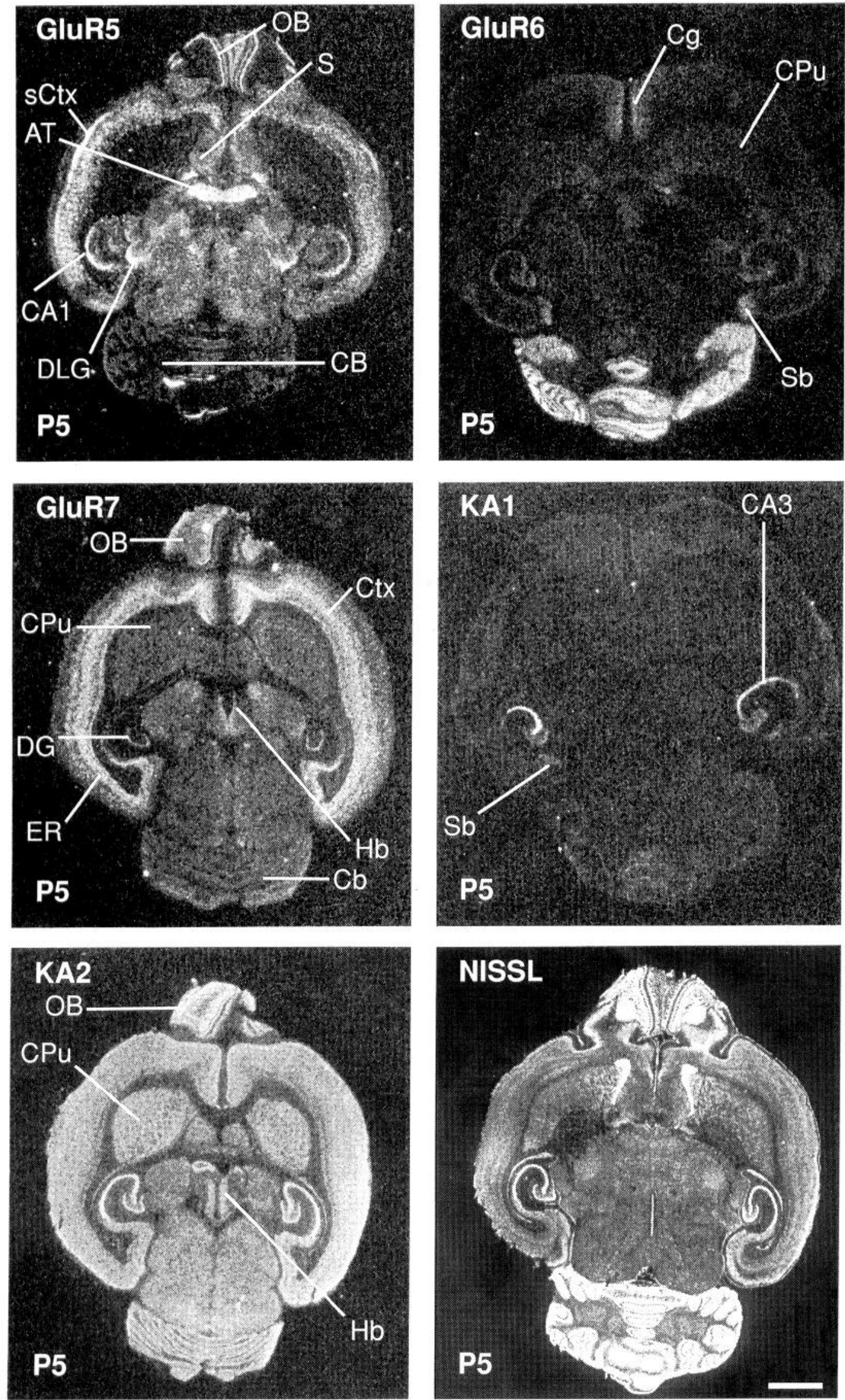

Figure 8. X-ray film autoradiographs illustrating distribution of kainate-preferring receptor subunit mRNAs encoding GluR-5, -6, -7, KA-1, and KA-2 subunits in horizontal sections of P5 rat brains. Nissl (thionin) stain of a corresponding section is shown in the bottom right panel. See Appendix for abbreviations. Scale bar, $2.1 \mathrm{~mm}$. 

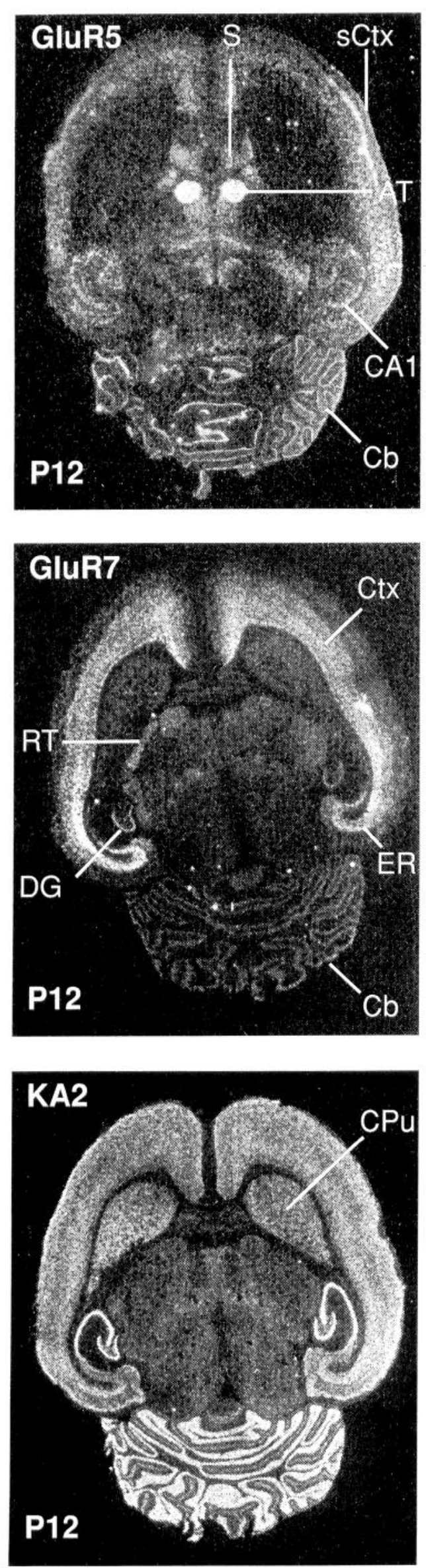
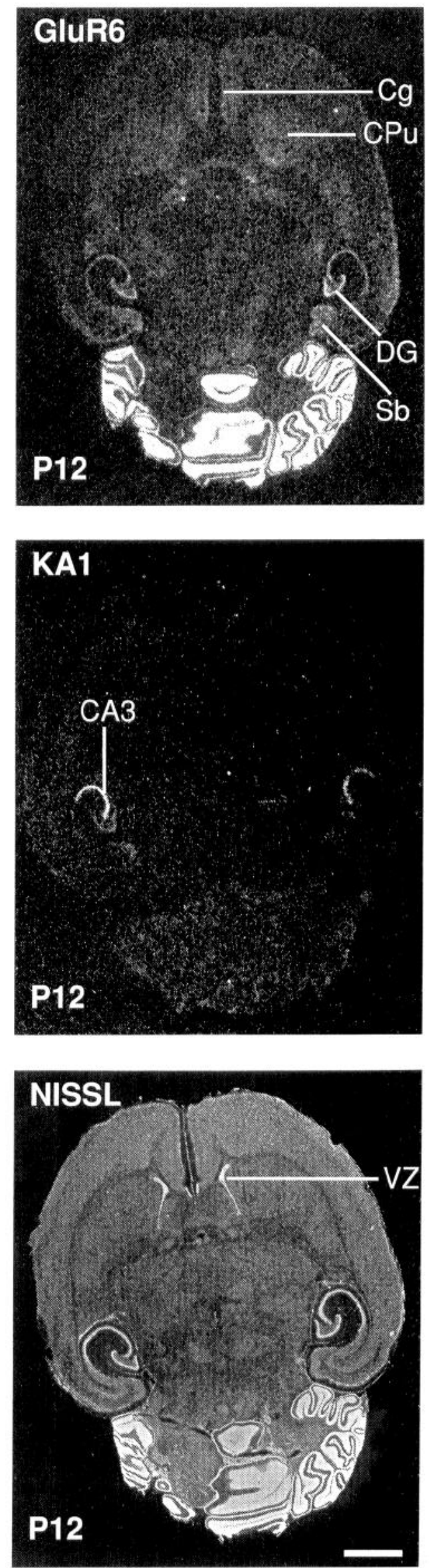

Figure 9. X-ray film autoradiographs illustrating distribution of kainate-preferring receptor subunit mRNAs encoding GluR-5, -6, -7, KA-1, and KA-2 subunits in horizontal sections of P12 rat brains. Nissl (thionin) stain of a corresponding section is shown in the bottom right panel. See Appendix for abbreviations. Scale bar, $2.1 \mathrm{~mm}$. 

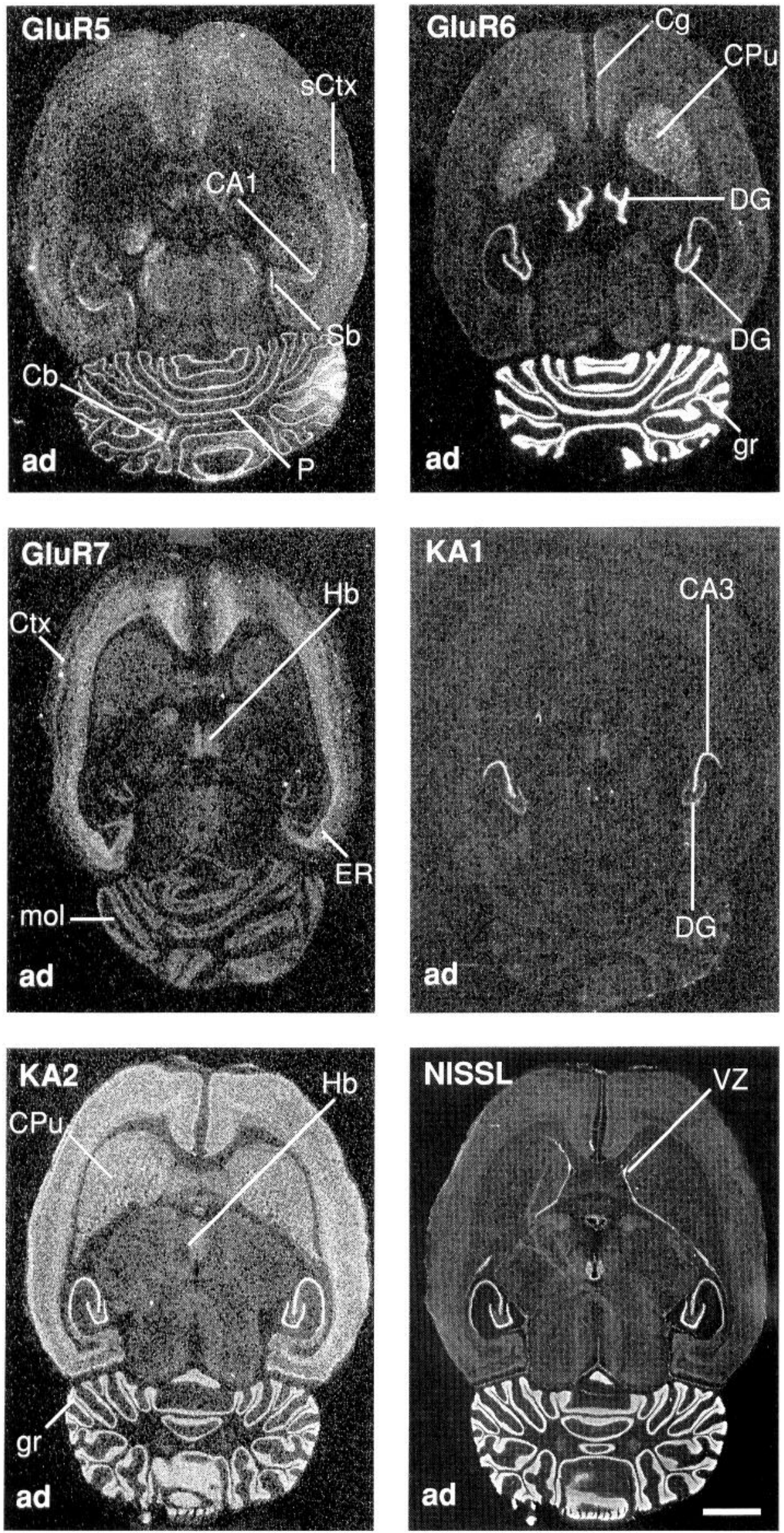

Figure 10. X-ray film autoradiographs illustrating distribution of kainate-preferring receptor subunit $\mathrm{mRNAs}$ encoding GluR-5, -6, -7, KA-1, and KA-2 subunits in horizontal sections of adult rat brains. Nissl (thionin) stain of a corresponding section is shown in the bottom right panel. See Appendix for abbreviations. Scale bar, $2.6 \mathrm{~mm}$. 

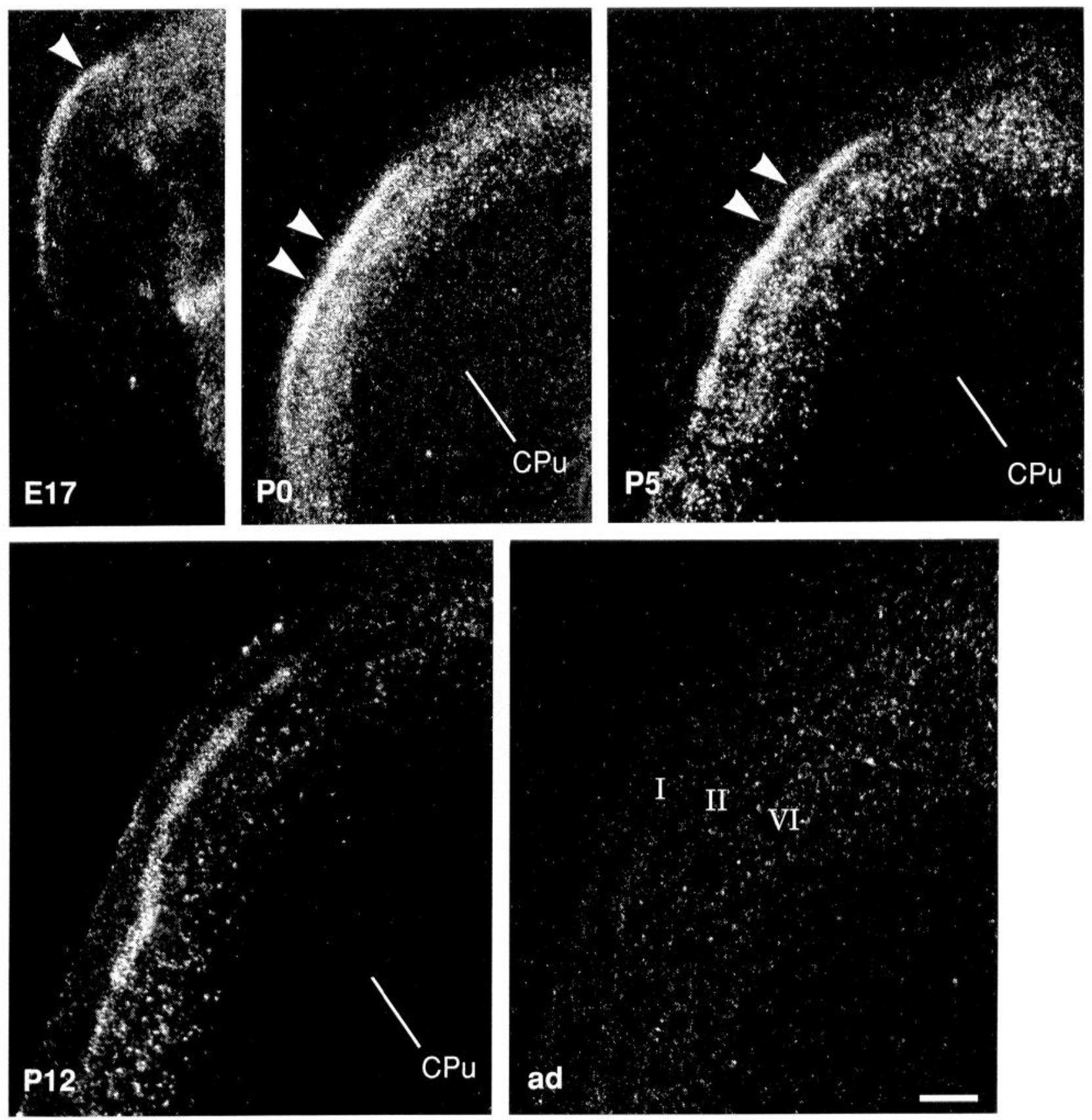

Figure 11. Enlargement of x-ray autoradiographs illustrating the expression of GluR-5 mRNA in the sensory cortex at different stages of brain development $(E 17, P 0, P 5, P 12$, adult). White arrowheads indicate the particularly intense line of expression in layer II/III cells in postnatal development. This line is absent in the adult. See Appendix for abbreviations. Scale bar, $0.7 \mathrm{~mm}$.

the same as that of the adult (Table 1), that is, KA-1, KA-2, GluR-6, GluR-7, and some GluR-5.

Of all the kainate receptor subunit genes, that of KA-1 has the most restricted expression in the CNS. In the adult, KA-1 subunit gene expression is a marker for CA3 pyramidal cells and dentate granule cells (Werner et al., 1991). KA-1 gene expression in the hippocampus first faintly appears at E17 (Fig. 5), and becomes better resolved at E19 (Fig. 6), where a tiny

Figure 12. Emulsion autoradiographs illustrating the cellular resolution of GluR-5 expression in the developing somatosensory cortex. Left column shows bright-field images, and right column shows the corresponding dark-field images. In $a$ and $b$, the arrowheads indicate the layer of positively hybridizing cells in the E19 sensory cortex. Neither the deeper layers of E19 cortex (marked by the stars), or cells in layer I express the GluR-5 gene. $c-f$ illustrate positive cells (arrowheads) that have appeared by $P 5$ in the deeper layers of sensory cortex as well as the continued labeling of cells in layer II/III. Most of the cells in the deeper layer are unlabeled. $e$ and $f$ are an enlargement of $c$ and $d$. The same area of adult cortex ( $g$, $h$ ) has far fewer labeled cells altogether, and none in the frame illustrated. Roman numerals indicate the cortical layers. Scale bars: $a$ and $b, 30 \mu \mathrm{m}$; $c-h, 50 \mu \mathrm{m}$. 

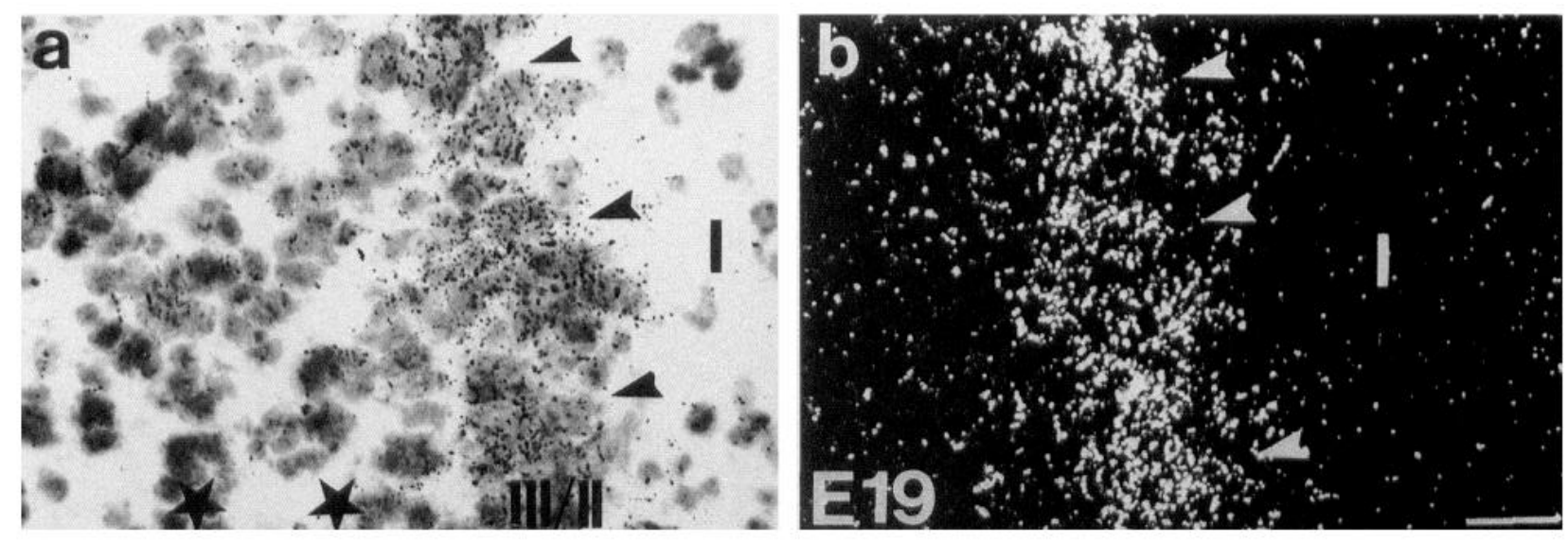

Con $0^{\circ}$ 16 - 4 - 2 a

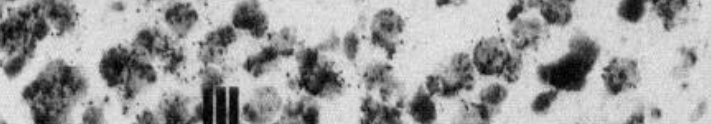
-3 ' N - + 3. 3 * :

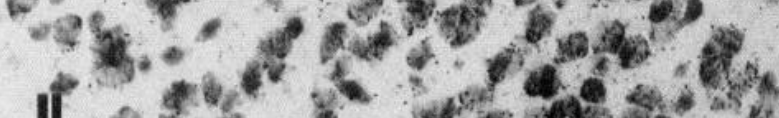

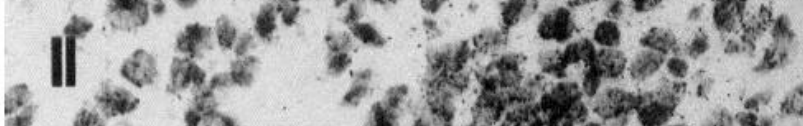

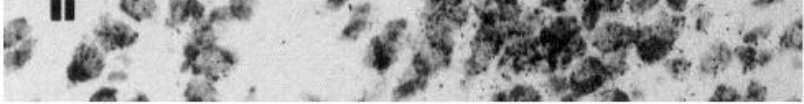

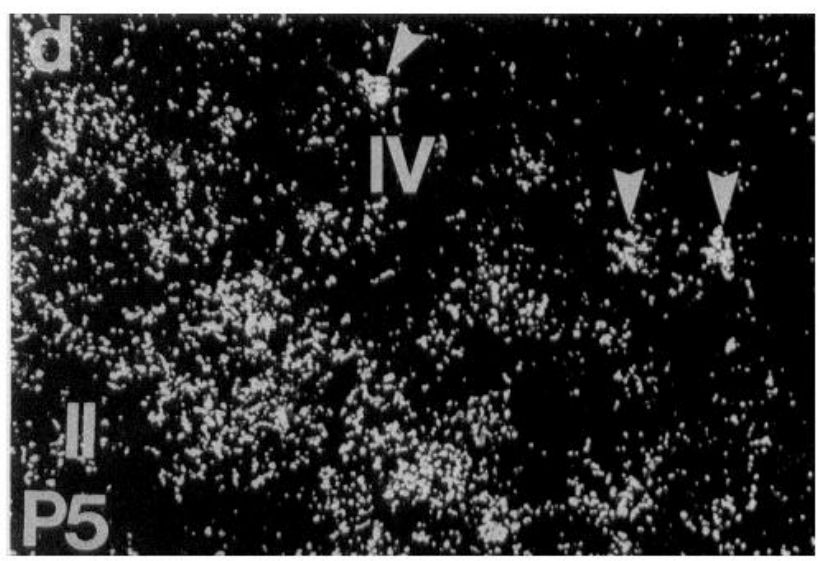

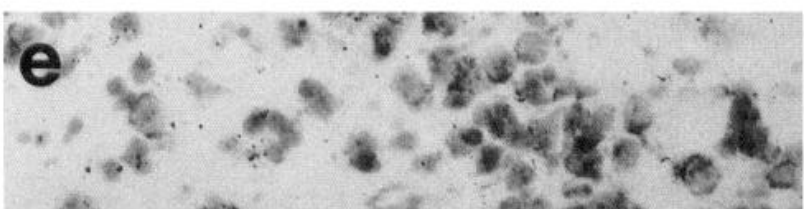

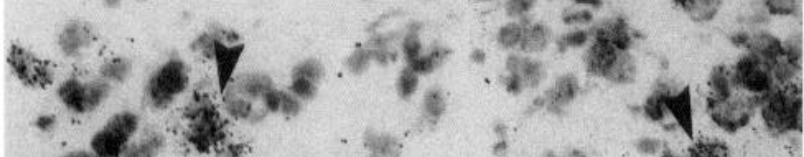
$2 y^{2} y=2$

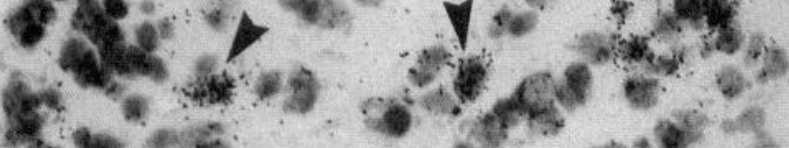
$x+2-z_{0}=8$

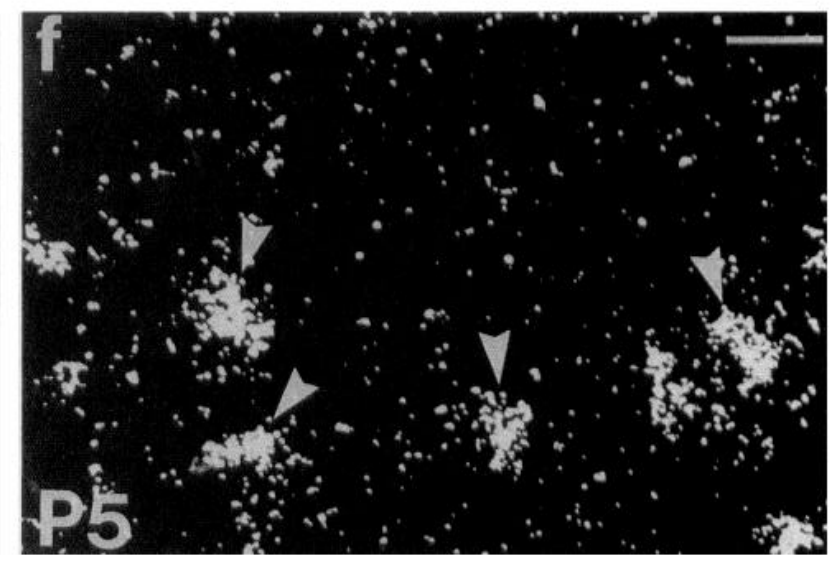

9.5?

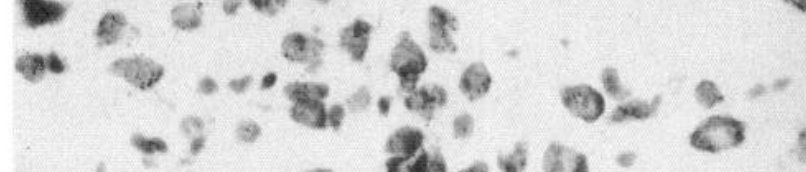
$\because \therefore 0^{\circ}$

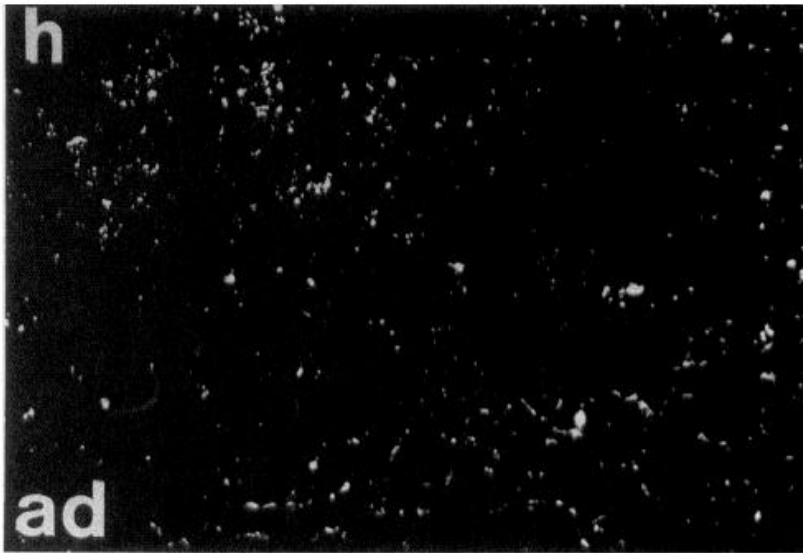



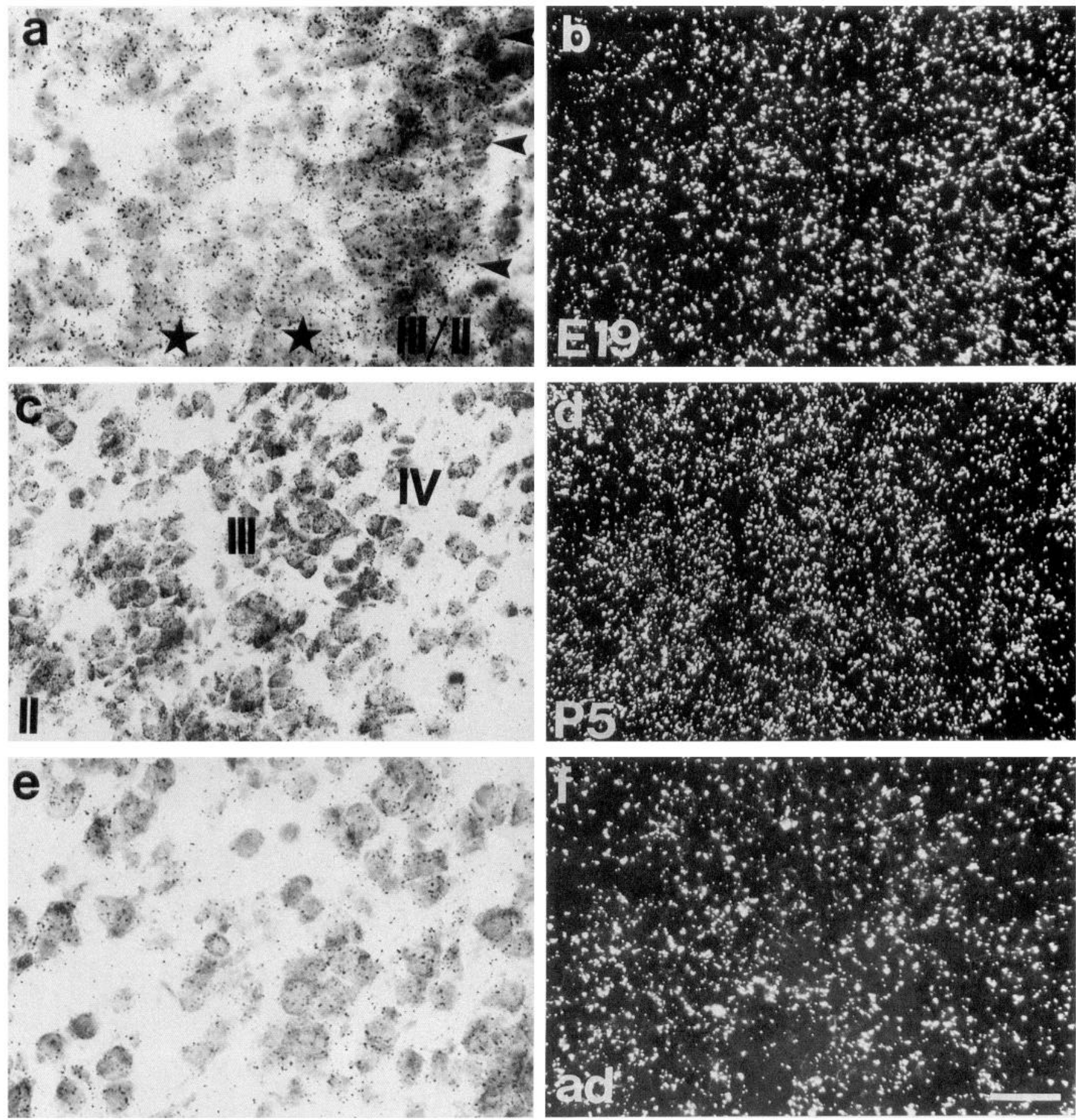

Figure 13. Emulsion autoradiographs illustrating the cellular resolution of KA-2 expression in the developing somatosensory cortex. Left column shows bright-field images, and right column shows the corresponding dark-field images. This plate is for comparison with Figure 12, and shows that in contrast to GluR-5, KA-2 is heavily and ubiquitously expressed in all cortical layers (except I) at all ages (E19, P5, adult) as seen by the profusion of silver grains. Roman numerals indicate cortical layers. Scale bar, $50 \mu \mathrm{m}$.

arch of expression marks out the CA3 region and a dot of signal marks the presumptive dentate (Fig. 6). The characteristic KA-1 pattern is already clearly defined at P0 (Fig. 7) and remains constant throughout development (Figs. 8-10). GluR-6 is also present in a CA3 to CA1 gradient in the adult (Egebjerg et al., 1991; Wisden and Seeburg, 1993b), but the development of this gradient is retarded compared with that for KA-1. For example, at $\mathrm{P} 0$ and $\mathrm{P} 5$ when $\mathrm{KA}-1$ expression is already cleanly parti- tioned between $\mathrm{CA} 1$ and $\mathrm{CA} 3$, GluR-6 is equiabundant in both sectors (Figs. 7, 8). GluR-6 mRNA increases in CA3 pyramidal cells during the late postnatal period (Figs. 9, 10).

\section{Expression peak of GluR-5 in the hippocampus}

In the $\mathrm{CA} 1$ region and the adjacent subiculum, there is a clear expression peak of GluR- 5 at stages $\mathrm{P} 0$ and $\mathrm{P} 5$ as assessed from $\mathrm{x}$-ray film (Fig. 14). This signal declines markedly by P12 and 

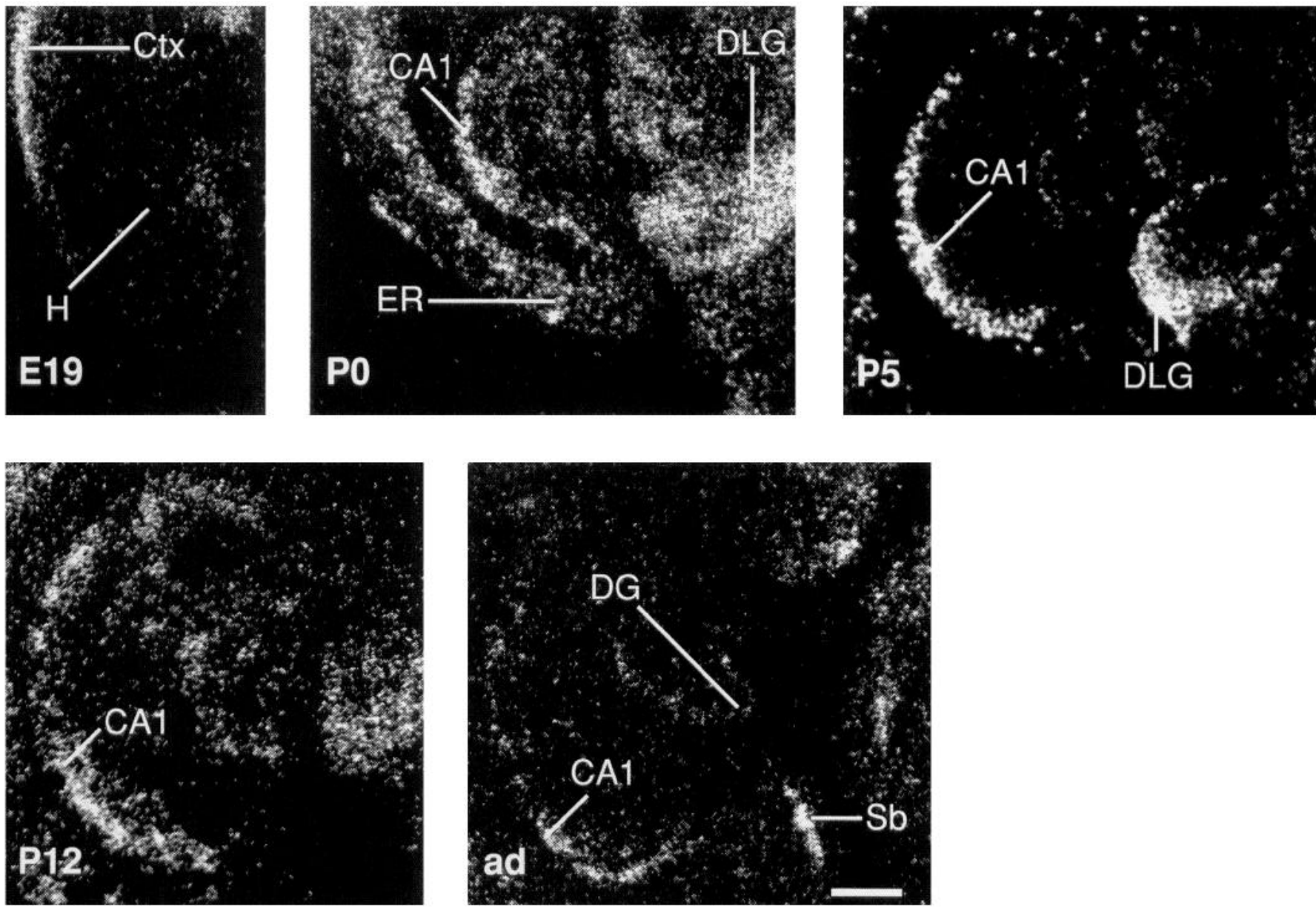

Figure 14. Enlargement of $\mathrm{x}$-ray autoradiographs illustrating the expression of GluR-5 mRNA in the hippocampal region at different stages of brain development ( $E 19, P O, P 5, P 12$, adult). At $E 19$ there is very little expression in the hippocampus as a whole. All images are printed to the same scale. See Appendix for abbreviations. Scale bar, $0.6 \mathrm{~mm}$.

is very diminished in the adult. Relatively little GluR-5 signal is present in CA3 or the dentate gyrus at any age (Fig. 14). At E17 there is very little GluR-5 expression in the hippocampus as a whole, whereas GluR-6 and KA-2 transcripts are already abundant at this stage (Fig. 5). This emphasizes that the GluR-5 signal in the developing hippocampus has a peak, rather than a decline in expression from some higher point.

Emulsion autoradiography reveals that the cells responsible for the transient GluR-5 signal are located in the stratum oriens (Fig. 15), and are probably nonpyramidal interneurons. At P0, many cells are strongly positive in the oriens layer (Fig. $15 b$, arrowheads), with the pyramidal cell layer at best lightly labeled. Through consequent stages, the number of GluR-5-positive oriens cells greatly diminishes until only a few remain in the adult (Fig. 15h, arrowheads). Consistent with our interpretation of these cells as interneurons, Craig et al. (1993) observe that GluR5-expressing cells from cultured embryonic rat hippocampus have the morphological characteristics of GABAergic interneurons. However, in these hippocampal primary cultures, no transient GluR-5 expression was seen, even though the cultures were maintained for 2 weeks from E19. Although, as is the case in vivo, the GluR-5-expressing cells in culture were a minority (approximately 20\%), GluR-5 expression in individual cells increased with age (Craig et al., 1993).

\section{Septum}

Only three of the five high-affinity kainate receptors are expressed in septal areas. The hybridization signal for GluR-5 is especially high, and as early as E14 already prominent. From E17 through to P5, the septum is a bright beacon of GluR-5 signal (Figs. 5-8). After P5 the labeling with the GluR-5 probes decreases significantly in the septum. The GluR-7 transcripts in this region show a peak at E1 7 and gradually decline thereafter from moderate $(\mathrm{E} 19, \mathrm{P} 0)$ to low levels. The expression of the KA-2 gene does not change during development of the septum. The ${ }^{3} \mathrm{H}$-kainic acid binding is detectable in the septum at E17 (Fig. 2), is very high at $\mathrm{P} 0$ and declines to moderate/low levels in the adult (Fig. 1). It might correlate with the GluR-5 gene expression pattern (i.e., a perinatal peak).

\section{Kainate receptor expression in the developing thalamus}

The developing diencephalon provides a further example of the heterogeneous expression of high-affinity kainate receptors. The KA-2 subunit transcripts are already ubiquitous in the mesencephalon at E12 and E14 and are expressed throughout this structure (Figs. 3, 4). In the following stages almost all subunits (except KA-1) are found in the thalamus. There is a very high expression of GluR-5 mRNA around birth (E19, P0) in certain 

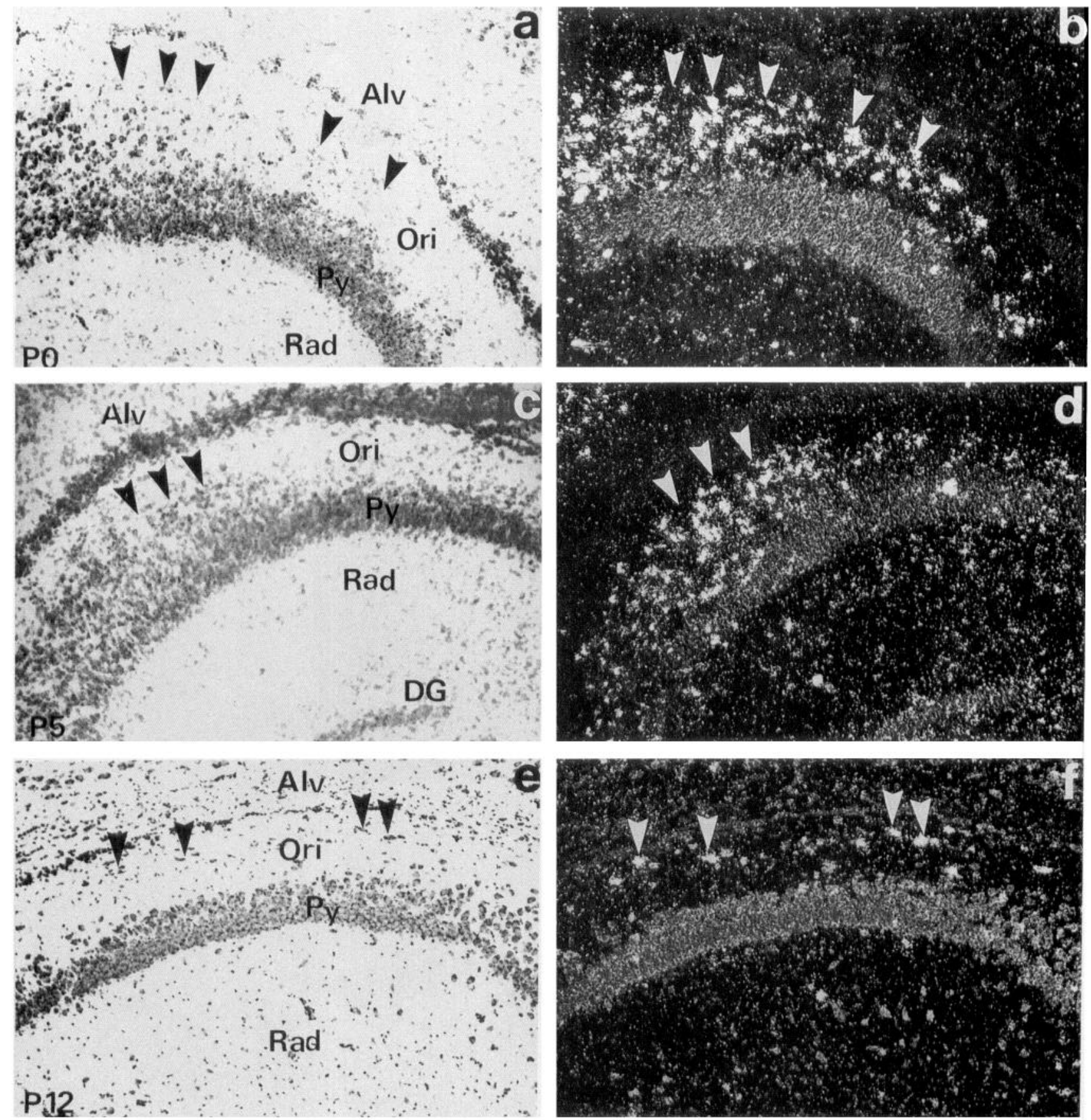

P12 -

$$
\text { Rad }
$$

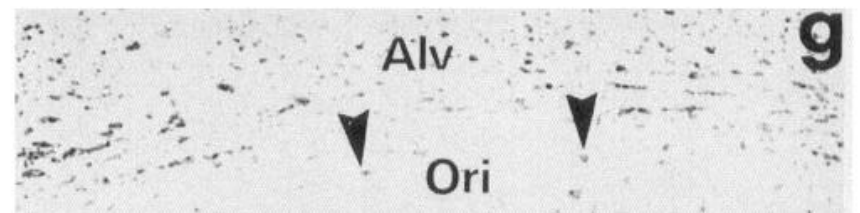

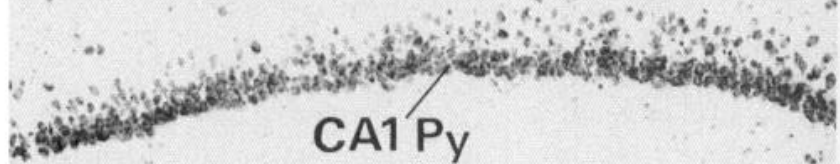

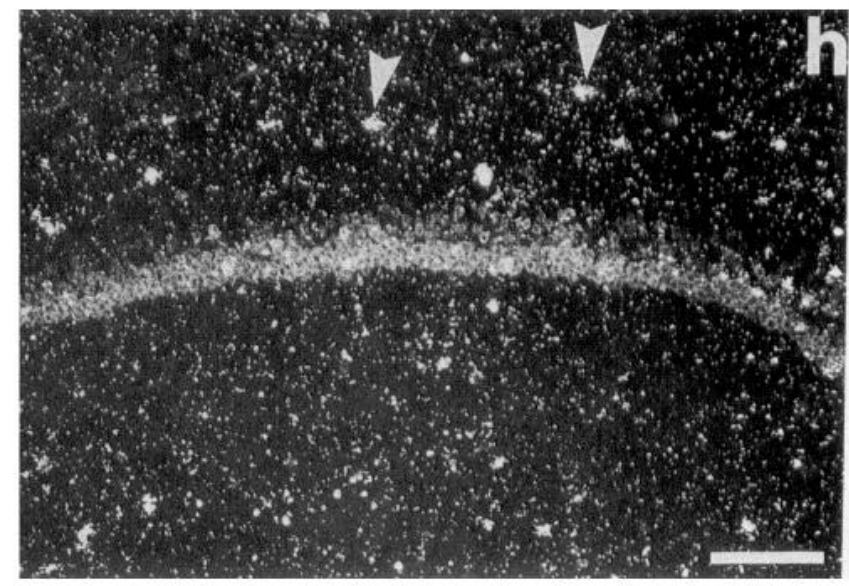

Rad 
nuclei, for example, the dorsal lateral geniculate and the anterior thalamic nuclei (Fig. 7), with a strong decline after P12.

In the adult thalamus, only the reticular area has an appreciable number of binding sites and GluR-7 predominates in this nucleus (Monaghan and Cotman, 1982; Unnerstall and Wamsley, 1983; Miller et al., 1990; Bettler et al., 1992; Lomeli et al., 1992; Wisden and Seeburg, 1993; and Figs. 1, 10). However, in the early postnatal period, the reticular thalamus expresses GluR-6 and KA-2 at comparable levels to GluR-7 (Fig. 7).

\section{Kainate receptor expression in the developing cerebellum}

The adult cerebellum has three cortical layers: the molecular layer, the Purkinje cell layer, and the granular layer (named in order from the outer surface), with the final structures of the cerebellum being formed by neuronal migration largely during postnatal development (Jacobson, 1991). Therefore, the expression of most high-affinity kainate receptors is restricted to the period of postnatal development. However, ${ }^{3} \mathrm{H}$-kainate binding is found over the primordial cerebellum (Fig. 2).

The localization of GluR-5 mRNA in the P0 cerebellum is diffuse (Fig. 7). By P5 a rather faint band over the multilayered Purkinje cells has appeared (cellular emulsion not shown). By P12, the hybridization signal is clearly over the single layered Purkinje cells; this pattern is maintained during adulthood. Purkinje cells also show KA- 1 gene expression. In the mouse, it has been observed that GluR-5 mRNA is abundant in immature granule cells, which then markedly downregulate the gene at a later period (Bettler et al., 1990). This does not seem to be the case in the rat, with no obviously strong expression of GluR-5 by granule cells at any age.

The GluR - 6 gene has its highest level of expression in granule cells in both the adult (Egebjerg et al., 1991, Fig. 10) and throughout development (e.g., at P5, Fig. 10). Transcripts for GluR-6 and KA-2 are observed in granule cells, with no striking developmental change. The pattern of labeling corresponds with the migration of these cells. At P0 the external granular cell layer is heavily labeled by the GluR- 6 and KA-2 probes as a thick band (Fig. 7); in the following stages P5 and P12, the signal increases in migrating cells and the internal granular cell layer with a slight expression peak of GluR-6 at P12 (Figs. 8, 9). In the cerebellum of the adult rat, GluR- 6 and KA-2 signals are restricted to the internal layer. The GluR-7 gene is expressed in the basket/stellate cells of the molecular layer throughout the postnatal period.

Perinatally, the ${ }^{3} \mathrm{H}$-kainic acid binding in the cerebellum is diffuse (Fig. 1); at P5 the granule cell and molecular layer labeling becomes more distinct increases with age (see also CambrayDeakin et al., 1990). Consistent with the expression of GluR-7 in the stellate/basket cells in the molecular layer, the possible expression of KA-1/GluR-5 on Purkinje cell dendrites, and GluR-6/KA-2 in the granule cell layer, both the granule and the molecular layers are labeled with ${ }^{3} \mathrm{H}$-kainate, with the granule cell layer always containing more sites at any age (see Monaghan and Cotman, 1982; Cambray-Deakin et al., 1990).

\section{Discussion}

We performed a systematic comparison of the distribution of the five high-affinity kainate receptor subunits (GluR-5, GluR6, GluR-7, KA-1, and KA-2) during development of the rat brain. Each of these subunits has a characteristic ontogenetic expression profile that begins as early as E12 (summarized in Table 1). The fact that kainate binding (as an index of protein formation) is not detectable until E14 (Fig. 1), even though transcripts are present at E12, may reflect a lag between the appearance of mRNA and significant accumulation of protein. In the mouse, where embryonic stages are approximately $2 \mathrm{~d}$ ahead of the rat (reviewed Laurie and Schrotz, 1994), GluR-5 mRNA is weakly detectable at E10, which is compatible with our results (Bettler et al., 1990). At rat embryonic stages E12 and E14, the migration and differentiation of the majority of neurons in the telencephalon and mesencephalon has not yet occurred (Jacobson, 1991), so that kainate receptors are likely to be synthesized on immature postmitotic neurons. At this very early stage, many synapses have not formed, so receptors might be extrasynaptic or located on dendritic growth cones. Similarly, in the early postnatal cerebellum, GluR-6 and KA-2 transcripts are detected in the external granule cell layer prior to their inward migration.

The role of kainate-preferring receptors in the brain is opaque. Based on their recombinant properties, they are predicted to form glutamate-gated cation channels that constitute a parallel system to those of the AMPA-preferring variety, but which rapidly desensitize to kainate. Kainate-preferring receptors can be distinguished from AMPA receptors by differential sensitivities to ConA and cyclothiozide (Partin et al., 1993). However, with the exception of the dorsal root ganglia in the periphery (Huettner, 1990; Partin et al., 1993), responses of kainate-preferring channels have not been reported when patch clamping CNS cells in slices (Jonas and Sakmann, 1992; reviewed by Wisden and Seeburg, 1993a,b). One possible reason for this is that functional kainate receptors could be largely located on distal dendrites (Vickers et al., 1993), and so elude detection by standard patch-clamping techniques. However, kainate has been found to activate a fully desensitizing current in a subset of cultured hippocampal cells of a small appearance (22\% of all cells studied) dissociated from E17 rat embryos when examined $4 \mathrm{hr}$ after plating and up to 3-4 d in culture (Lerma et al., 1993). This response most clearly matched GluR-6(Q) homomeric responses. With neurons kept for longer periods, the AMPA/lowaffinity kainate (nondesensitizing) response predominated (Lerma et al., 1993). The in situ hybridization and immunocytochemistry studies predict that most types of hippocampal neurons (e.g., pyramidal cells) would express kainate-preferring receptors, again suggesting that the architectural features of many neurons might preclude the electrophysiological detection of kainate receptors.

In the developing brain, a dendritic location of kainate receptors might be used to elicit very local cytoarchitectural changes

\footnotetext{
Figure 15. Emulsion autoradiographs illustrating cellular resolution of GluR-5-expressing cells in the stratum oriens of the developing hippocampus. Left column shows the Nissl stain (bright-field) and right column shows the corresponding dark-field images. Arrowheads indicate examples of labeled cells. Many cells are labelled at P0, whereas only a few cells are labeled in the stratum oriens of the adult $(g, h)$. See appendix for abbreviations. Scale bar, $400 \mu \mathrm{m}$.
} 
of the dendritic tree. Growth rates of developing dendrites can be slowed down by focal application of physiological concentrations of glutamate or kainate to individual growth cones (Mattson et al., 1988a). These regressive effects of kainate are mediated by ionotropic receptors located on the growth cone (Mattson et al., 1988a,b) and would be in keeping with dendritic locations seen in the adult (Huntley et al., 1993; Vickers et al., 1993). In a study using cultured cerebellar granule cells, kainate $(60 \mu \mathrm{M})$ enhanced neurite development (both elongation and sprouting), whereas AMPA (20 $\mu \mathrm{M})$ had no effect (Pizzi et al., 1994). This observation might further support the idea of kainate-selective receptors that are present on dendrites or axons. Immunocytochemistry with an antibody that cross-reacts with the GluR-5, GluR-6, and GluR-7 subunits shows that these subunits are particularly enriched on dendritic shafts (Huntley et al., 1993; Vickers et al., 1993), although this has not been so far examined in the developing CNS.

\section{Kainate receptor configurations in development}

The electrophysiology of recombinant subunits and immunoprecipitation studies from native brain membranes suggest that some kainate-preferring receptors probably exist in vivo as heteromeric assemblies of different types of subunit, for example, GluR-6/KA-2 (Herb et al., 1992; Sakimura et al., 1992; Wenthold et al., 1993). GluR-5 and GluR-6 can also function in homomeric configurations in vitro (Egebjerg et al., 1991; Sommer et al., 1992), but whether they exist like this in vivo is unknown. Thus, a specific aim was to examine possible partnership relations among different high-affinity kainate receptor subunits during development. Generally, as far as can be seen by in situ hybridization, and with the exception of GluR-5 (see below), these are probably the same as in the adult brain (see Wisden and Seeburg, 1993b), although there are likely to be subtle differences (see Results). However, the intensification/ exaggeration of the adult patterns seen in the early postnatal period may indicate an importance of these receptors in perinatal plasticity. Alternatively, the postnatal intensification of the adult pattern might represent peaks of cell populations, many cells of which are then eliminated during the normal course of neurogenesis (see below).

\section{High-affinity kainate binding sites as markers of subunit composition?}

There are two high-affinity kainate binding sites found on brain membranes of $K_{D}$ of 5 and $50 \mathrm{nM}$, respectively (Coyle, 1983; Hampson et al., 1987), and these have essentially the same distribution as determined by autoradiography (Monaghan and Cotman, 1982; Unnerstall and Wamsley 1983; Miller et al., 1990). The relative proportion of these two sites in some brain areas changes during development, although as in the adult, the qualitative distribution pattern of the two sites is more or less identical (Miller et al., 1990). At first sight, these two sites are reflected in the recombinant kainate receptor subunits: homomeric KA-subunits have $K_{D} \sim$ 5-10 nM (Werner et al., 1991; Herb et al., 1992), while homomeric configurations of GluR-5, -6 , and -7 average $\sim 50-100 \mathrm{nM} K_{D}$ for kainate (Bettler et al., 1992; Lomeli et al., 1992; Sommer et al., 1992). However, since homomeric cloned KA subunits do not form functional ion channels, but assuming that they do so in vivo as partners with the GluR subunits, it is difficult to know how to precisely relate the binding to the recombinant data. For example, taking the results of Miller et al. (1990), the affinity $\left(K_{D}\right)$ of kainate sites in the reticular thalamic nucleus is 14.7 at $\mathrm{P} 14$ and 6.3 in the adult. However, in the adult (and largely throughout development) the only kainate subunit abundantly detectable by in situ hybridization is that of GluR-7, with some low levels of KA-2 and GluR-6 mRNA also present (Wisden and Seeburg, 1993b). Yet the recombinant form of GluR-7 has a $K_{D}$ for kainate of $\sim 70 \mathrm{~nm}$ (Bettler et al., 1992; Lomeli et al., 1992), so it is hard to see how the reported $K_{D}$ of 6.3 for the adult reticular thalamic nucleus correlates with the subunit composition in this area. Similarly, the $K_{D}$ for kainate in CA3 at $14 \mathrm{~d}$ is 7.8 , and in the adult, 5.8 (Miller et al., 1990), yet this region expresses GluR6, KA-1, and KA-2 throughout development. If CA3 pyramidal cells assemble functional KA-1/KA-2/GluR- 6 channels, the $K_{D}$ would be predicted to be between 50 and $100 \mathrm{~nm}$ based on expressing the cloned subunits on human embryonic kidney or HeLa cells (Bettler et al., 1992; Herb et al., 1992). In any case, even if the CA3 $K_{D}$ is due to homomeric KA-subunits, GluR-6 mRNA (and probably protein) is abundant in these cells (Egebjerg et al., 1991; Wisden and Seeburg, 1993b). Alternatively, some of the binding sites in CA3 stratum lucidum could be presynaptic, resulting from kainate receptors on mossy fiber terminals derived from the dentate granule cells (Represa et al., 1987). However, even in this instance, based on mRNA expression profiles in the dentate granule cells, we might still expect the GluR- 6 and GluR-7 subunits in addition to those of KA-1 and $\mathrm{KA}-2$ to be present. In order to explain the $K_{D}$ values, one would have to argue for a selective sorting of just the KAsubunits into the mossy fibers. The use of subunit-specific antibodies should resolve this point. It is also possible that in neuronal membranes, rather than in the epithelial cells used for the recombinant studies, the subunits exhibit different affinities.

\section{A special role for GluR-5 in the developing CNS?}

In contrast to the other subunits, the GluR-5 gene undergoes many clear qualitative changes in its expression over time, as is particularly clear from the developing sensory cortex (see Fig. 11). In the sensory cortex, the GluR-5 subunit shows a distinct perinatal peak in layers II, III, and IV. The very intense signal in layer II appears as a homogeneous band on the x-ray autoradiographs, whereas the distribution in layers III and IV is more punctate. The time course of this GluR-5 expression peak is consistent with the period of greatest developmental plasticity in the somatosensory cortex, that is, formation of the "barrels," the somatotopic representation of the sensory vibrissae in rodents (Jacobson, 1991). These barrels are composed of small aggregates of layer IV neurons, innervated by clusters of thalamocortical afferents. Barrel formation takes place during the first $24 \mathrm{hr}$ after birth (P0). Interestingly, Shlaggar et al. (1993) report that chronic blockade of ionotropic glutamate receptors during this time interferes with barrel formation in the developing rat. These observations may be suggestive of a role of the GluR-5 subunit in plasticity dependent processes. The changes in GluR-5 expression are specific to just one region of developing cortex.

A further indication of a possible "special" role of GluR-5 in development is that GluR-5 transcripts similarly peak in the septum, thalamus, CAl interneurons of the hippocampus in the stratum oriens (Figs. 14, 15). Peaks of ${ }^{3} \mathrm{H}$-kainic acid binding are seen especially in the thalamus, $\mathrm{CAl}$ and subiculum (Miller et al., 1990; Garcia-Ladona and Gombos, 1993; present results). These binding peaks possibly correspond to GluR-5 expression, although there is no obvious binding peak in the somatosensory 
cortex with respect to other areas of the cortex. In the hippocampus, a whole large population of GluR-5-expressing interneurons in the stratum oriens appears to switch off this gene (Fig. 15).

An alternative for the GluR-5 expression peaks in these areas is that they represent a transient population of cells. In many parts of the developing vertebrate CNS, up to half of the neuronal population is eliminated in the cause of quantitative adjustments of interconnecting populations of neurons and in the elimination of aberrant projections (reviewed by Oppenheim, 1991). NMDA receptors are suggested to be one conduit used for an excitotoxic culling of cells, since NMDA receptor blockade with MK-801 during development results in increases in neuronal numbers in the adult (Mentis et al., 1993; Mount et al., 1993; O'Donoghue et al., 1993). So, rather than a gene regulation/switch, it is possible that the decline of GluR-5 expression (e.g., in the cortex, septum, and thalamus) is due to cell death of specific cell populations expressing GluR-5. The GluR-5 subunit might exert a direct excitotoxic effect on the cell in which it is expressed. A precedent is that overexpression of the related GluR-6 subunit in CA3 hippocampal neurons leads to cell death (Bergold et al., 1993).

The GluR-5 and GluR-6 subunits each exist in several versions, some of which are permeable to calcium, since critical amino acids determining ion selectivity in putative transmembrane domains can be substituted by RNA editing (Sommer et al., 1991, 1992; Egebjerg and Heinemann, 1993; Köhler et al., 1993). Editing the different forms of GluR-5 could occur at varying frequencies in the CNS during development (Sommer et al., 1991; Köhler et al., 1993). It would be interesting to examine by single cell PCR/patch-clamp methods (Lambolez et al., 1992; Mackler and Eberwine, 1993) the relative numbers of edited versions of GluR-5 mRNAs in cells taken from different ages of somatosensory cortex. It might also be worthwhile to look at the numbers of calcium permeable kainate receptors in this area of developing cortex using the cobalt histochemical assay (Pruss et al., 1991).

\section{General changes in other ionotropic EAA receptors in development}

Some NMDA, AMPA, and $\delta$ ionotropic glutamate receptor subunit genes also markedly change their expression during development. These changes are often found in similar brain regions to those of the high-affinity kainate receptors (Insel et al., 1990; Monyer et al., 1991, 1994; Pellegrini-Giampietro et al., 1991, 1992; Gallo et al., 1992; Watanabe et al., 1992; Lomeli et al., 1993). Any developmental effects of changes in high-affinity kainate receptor expression probably occur in concert with these other receptors. For example, the NR2D ( $\epsilon 4)$ NMDA receptor subunit gene is highly expressed in the embryonic and early postnatal thalamus, but strongly downregulated in the adult (Watanabe et al., 1992; Monyer et al., 1994). This situation parallels the changes seen in GluR-5 gene expression in these regions during the same period of development and might represent a functionally related event.

\section{Conclusions}

Kainate-preferring receptors are expressed from an early age (E12/E14) in both peripheral and central neurons. Changes in the subunit composition of these receptors probably take place during brain development. In particular, the GluR-5 subunit gene is markedly regulated in the sensory cortex, thalamus, and
CA1 interneurons, and it might be worth focusing future efforts on understanding the exact role of this subunit during brain development.

\section{Appendix}

$\begin{array}{ll}\text { Abbreviations used in figures } \\ \text { AT } & \text { anterior thalamus } \\ \text { ca } & \text { Cerebral aqueduct } \\ \text { CA1 } & \text { CA1 region of hippocampus } \\ \text { CA3 } & \text { CA3 region of hippocampus } \\ \text { Cb } & \text { Cerebellum } \\ \text { Cg } & \text { Cingulate gyrus } \\ \text { CNG } & \text { Cranial nerve ganglia } \\ \text { CPu } & \text { Corpus putamen } \\ \text { ct } & \text { Cartilage } \\ \text { Ctx } & \text { Cortex } \\ \text { DG } & \text { Dentate gyrus } \\ \text { DLG } & \text { Dorsal lateral geniculate nucleus } \\ \text { DRG } & \text { Dorsal root ganglia } \\ \text { E } & \text { Eye } \\ \text { ER } & \text { Entorhinal cortex } \\ \text { gr } & \text { Granule cell layer of cerebellum } \\ \text { H } & \text { Hippocampus } \\ \text { Hb } & \text { Habenula } \\ \text { ht } & \text { Heart } \\ \text { li } & \text { Liver } \\ \text { MG } & \text { Mural ganglia } \\ \text { mes } & \text { Mesencephalon } \\ \text { MLG } & \text { Medial lateral geniculate nucleus } \\ \text { mol } & \text { Molecular layer of cerebellum } \\ \text { OB } & \text { Olfactory bulb } \\ \text { OEp } & \text { Olfactory epithelium } \\ \text { P } & \text { Purkinje cell layer of cerebellum } \\ \text { Pn } & \text { Pons } \\ \text { R } & \text { Retina } \\ \text { rT } & \text { Reticular thalamus } \\ \text { S } & \text { Septum } \\ \text { Sb } & \text { Subiculum (including presubiculum and parasubiculum) } \\ \text { SC } & \text { Spinal cord } \\ \text { sCtx } & \text { Sensory cortex } \\ \text { Skl } & \text { Skull } \\ \text { St } & \text { Striatum } \\ \text { T } & \text { Thalamus } \\ \text { Te } & \text { Telencephalon } \\ \text { V } & \text { Follicles of vibrissae } \\ \text { VZ } & \text { Ventricular zone } \\ & \end{array}$

\section{References}

Balázs R, Jorgensen OS, Hack N (1988) N-Methyl-D-aspartate promotes the survival of cerebellar granule cells in culture. Neuroscience 27:437-451.

Bergold PJ, Casaccia-Bonnefil P, Xiu-Liu Z, Federoff HJ (1993) Transynaptic neuronal loss induced in hippocampal slice cultures by a herpes simplex virus vector expressing the GluR6 subunit of the kainate receptor. Proc Natl Acad Sci USA 90:6165-6169.

Bettler B, Boulter J, Hermans-Borgmeyer I, O'Shea-Greenfield A, Deneris ES, Moll C, Borgmeyer U, Hollmann M, Heinemann S (1990) Cloning of a novel glutamate receptor subunit, GluR5: expression in the nervous system during development. Neuron 5:583-595.

Bettler B, Egebjerg J, Sharma G, Pecht G, Hermans-Borgmeyer I, Moll C, Stevens CF, Heinemann S (1992) Cloning of a putative glutamate receptor: a low affinity kainate-binding subunit. Neuron 8:257-265.

Bodnarenko SR, Chalupa LM (1993) Stratification of ON and OFF ganglion cell dendrites depends on glutamate-mediated afferent activity in the developing retina. Nature 364:144-146.

Cambray-Deakin MA, Foster AC, Burgoyne RD (1990) The expression of excitatory amino acid binding sites during neuritogenesis in the developing rat cerebellum. Dev Brain Res 54:265-271.

Carmignoto G, Vicini S (1992) Activity-dependent decrease in NMDA receptor responses during development of the visual cortex. Science 258:1007-1011.

Cox JA, Felder CC, Henneberry RC (1990) Differential expression of 
excitatory amino acid receptor subtypes in cultured cerebellar neurons. Neuron 4:941-947.

Coyle JT (1983) Neurotoxic action of kainic acid. J Neurochem 41: $1-11$.

Craig AM, Blackstone CD, Huganir RL, Banker G (1993) The distribution of glutamate receptors in cultured hippocampal neurons: postsynaptic clustering of AMPA-selective subunits. Neuron 10:10551068.

Egebjerg J, Heinemann SF (1993) $\mathrm{Ca}^{2+}$ permeability of unedited and edited versions of the kainate selective glutamate receptor GluR6. Proc Natl Acad Sci USA 90:755-759.

Egebjerg J, Bettler B, Hermans-Borgmeyer I, Heinemann S (1991) Cloning of a cDNA for a glutamate receptor subunit activated by kainate but not AMPA. Nature 351:745-748.

Foster AC, Mena EE, Monaghan DT, Cotman CW (1981) Synaptic localization of kainic acid binding sites. Nature 289:73-75

Gallo V, Upson LM, Hayes WP, Vyklicky L Jr, Winters CA, Buonanno A (1992) Molecular cloning and developmental analysis of a new glutamate receptor subunit isoform in cerebellum. J Neurosci 12 $1010-1023$.

Garcia-Ladona FJ, Gombos G (1993) Regional distribution of transient $\left[{ }^{3} \mathrm{H}\right]$ kainic acid-binding sites in the central nervous system of the developing mouse: an autoradiographic study. Neurosci Lett 151: 209-213.

Gasic GP, Hollmann M (1992) Molecular neurobiology of glutamate receptors. Annu Rev Physiol 54:507-536.

Gould E, McEwen BS (1993) Neuronal birth and death. Curr Opin Neurobiol 3:676-682.

Hack N, Hidaka H, Wakefield MJ, Balázs R (1993) Promotion of granule cell survival by high $\mathrm{K}^{+}$or excitatory amino acid treatment and $\mathrm{Ca}^{2+} /$ calmodulin-dependent protein kinase activity. Neuroscience 57:9-20.

Hampson DR, Huie D, Wenthold RJ (1987) Solubilization of kainic acid binding sites from rat brain. $J$ Neurochem 49:1209-1215.

Herb A, Burnashev N, Werner P, Sakmann B, Wisden W, Seeburg PH (1992) The KA-2 subunit of excitatory amino acid receptors shows widespread expression in brain and forms ion channels with distantly related subunits. Neuron 8:775-785.

Huettner JE (1990) Glutamate receptor channels in rat DRG neurons: activation by kainate and quisqualate and blockade of desensitization by Con $A$. Neuron 5:255-266.

Huntley GW, Rogers SW, Moran T, Janssen W, Archin N, Vickers JC, Cauley K, Heinemann SF, Morrison JH (1993) Selective distribution of kainate receptor subunit immunoreactivity in monkey neocortex revealed by a monoclonal antibody that recognizes glutamate receptor subunits GluR5/6/7. J Neurosci 13:2965-2981.

Insel TR, Miller LP, Gelhard RE (1990) The ontogeny of excitatory amino acid receptors in rat forebrain. I. $N$-methyl-D-aspartate and quisqualate receptors. Neuroscience $35: 31-43$.

Jacobson M (1991) Developmental neurobiology, 3d ed. New York: Plenum.

Jonas P, Sakmann B (1992) Glutamate receptor channels in isolated patches from CA1 and CA3 pyramidal cells of rat hippocampal slices. J Physiol (Lond) 455:143-171.

Kalb RG, Hockfield S (1990) Induction of a neuronal proteoglycan by the NMDA receptor in the developing spinal cord. Science 250 294-296.

Kaufmann MH (1992) The atlas of mouse development. London: Academic.

Kleinschmidt A, Bear MF, Singer W (1987) Blockade of NMDA receptors disrupts experience-dependent plasticity of kitten striate cortex. Science 238:355-358.

Köhler M, Burnashev N, Sakmann B, Seeburg PH (1993) Determinants of $\mathrm{Ca}^{2+}$ permeability in both TM1 and TM2 of high affinity kainate receptor channels: diversity by RNA editing. Neuron 10:491500

Komuro H, Rakic P (1993) Modulation of neuronal migration by NMDA receptors. Science 260:95-97.

Lambolez B, Audinat E, Bochet P, Crépel F, Rossier J (1992) AMPA receptor subunits expressed by single Purkinje cells. Neuron 9:247258.

Laurie DJ, Schrotz PCU (1994) Processing vertebrate embryonic and early postnatal tissue for in situ hybridization. In: In situ hybridization protocols for the brain (Wisden W, Morris BJ, eds), in press. London: Academic.
Lerma J, Paternain AV, Naranjo JR, Mellström B (1993) Functional kainate-selective glutamate receptors in cultured hippocampal neurons. Proc Natl Acad Sci USA 90:11688-11692.

Lomeli H, Wisden W, Köhler M, Keinänen K, Sommer B, Seeburg PH (1992) High-affinity kainate and domoate receptors in rat brain. FEBS Lett 307:139-143.

Lomeli H, Sprengel R, Laurie DJ, Köhr G, Herb A, Seeburg PH, Wisden W (1993) The rat delta-1 and delta-2 subunits extend the excitatory amino acid receptor family. FEBS Lett 315:318-322.

Mackler SA, Eberwine JH (1993) Diversity of glutamate receptor subunit mRNA expression within live hippocampal CA1 neurons. Mol Pharmacol 44:308-315.

Mattson MP, Dou P, Kater SB (1988a) Outgrowth-regulating actions of glutamate in isolated hippocampal pyramidal neurons. J Neurosci 8:2087-2100.

Mattson MP, Lee RE, Adams ME, Gutherie PB, Kater SB (1988b) Interactions between entorhinal axons and target hippocampal neurons: a role for glutamate in the development of hippocampal circuitry. Neuron 1:865-876.

McDonald JW, Johnston MV (1990) Physiological and pathophysiological roles of excitatory amino acids during central nervous system development. Brain Res Rev 15:41-70.

Mentis GZ, Greensmith L, Vrbová G (1993) Motor neurons destined to die are rescued by blocking $N$-methyl-D-aspartate receptors by MK 801. Neuroscience 54:283-285.

Miller LP, Johnson AE, Gelhard RE, Insel TR (1990) The ontogeny of excitatory amino acid receptors in the rat forebrain. II. Kainic acid receptors. Neuroscience 35:45-51.

Monaghan DT (1993) Autoradiographic analysis of excitatory amino acid receptors. In: Receptor autoradiography: principles and practice (Wharton J, Polak JM, eds). London: Oxford UP.

Monaghan DT, Anderson KJ (1991) Heterogeneity and organization of excitatory amino acid receptors and transporters. In: Excitatory amino acids and synaptic function (Wheal $H$, Thompson $A$, eds), pp 35-54. Sydney: Academic.

Monaghan DT, Cotman CW (1982) The distribution of [ $\left.{ }^{3} \mathrm{H}\right]$ kainic acid binding sites in rat CNS as determined by autoradiography. Brain Res 252:91-100.

Monaghan DT, Nguyen L, Cotman CW (1986) The distribution of $\left[{ }^{3} \mathrm{H}\right] \mathrm{kainate}$ binding sites in primate hippocampus is similar to the distribution of both $\mathrm{Ca}^{2+}$-sensitive and $\mathrm{Ca}^{2+}$-insensitive $\left[{ }^{3} \mathrm{H}\right] \mathrm{kainate}$ binding sites in rat hippocampus. Neurochem Res 11:1073-1082.

Monyer HP, Seeburg H, Wisden W (1991) Glutamate-operated channels: developmentally early and mature forms arise by alternative splicing. Neuron 6:799-810.

Monyer H, Burnashev N, Laurie DJ, Sakmann B, Seeburg PH (1994) Developmental and regional expression in the rat brain and functional properties of four NMDA receptor subtypes. Neuron, in press.

Mount HTI, Dreyfus CF, Black IB (1993) Purkinje cell survival is differentially regulated by metabotropic and ionotropic excitatory amino acid receptors. J Neurosci 13:3173-3179.

Nakanishi S (1992) Molccular diversity of glutamate receptors and implications for brain function. Science 258:597-603.

O'Donoghue DL, PoffCRD, Block JJ (1993) Chronic neonatal $N$-methyl-D-aspartate receptor antagonism with MK-801 increases the number of corticospinal cells retained into adulthood in the rat. Neurosci Lett 158:143-146.

Oppenheim RW (1991) Cell death during development of the nervous system. Annu Rev Neurosci 14:453-501.

Partin KM, Patneau DK, Winters CA, Mayer ML, Buonanno A (1993) Selective modulation of desensitization at AMPA versus kainate receptors by cyclothiozide and concanavalin A. Neuron 11:1069-1082.

Paxinos G, Watson C (1986) The rat brain in stereotaxic coordinates, 2d ed. Sydney: Academic.

Paxinos G, Törk I, Tecott LH, Valentino KL (1991) Atlas of developing rat brain. San Diego: Academic.

Pearce IA, Cambray-Deakin MA, Burgoyne RD (1987) Glutamate acting on NMDA receptors stimulates neurite outgrowth from cerebellar granule cells. FEBS Lett 223:143-147.

Pellegrini-Giampietro DE, Bennett MVL, Zukin RS (1991) Differential expression of three glutamate receptor genes in the developing brain: an in situ hybridization study. Proc Natl Acad Sci USA 88: $4157-4161$

Pellegrini-Giampietro DE, Bennett MVL, Zukin RS (1992) $\mathrm{Are} \mathrm{Ca}^{2+}$ 
permeable kainate/AMPA receptors more abundant in immature brain? Neurosci Lett 144:65-69.

Pizzi M, Fallacara C, Consolandi O, Memo M, Spano PF (1994) $\alpha$ Amino-3-hydroxy-5-methyl-4-isoxazolepropionate and kainate differently affect neuronal cytoarchitecture of rat cerebellar granule cells. Neurosci Lett 166:77-80.

Pruss RM, Akeson RL, Racke MM, Wilburn JL (1991) Agonist-activated cobalt uptake identifies divalent cation-permeable kainate receptors on neurons and glial cells. Neuron 7:509-518.

Raymond LA, Blackstone CD, Huganir RL (1993) Phosphorylation and modulation of recombinant GluR6 glutamate receptors by cAMPdependent protein kinase. Nature 361:637-641.

Represa A, Tremblay E, Ben-Ari Y (1987) Kainate binding sites in the hippocampal mossy fibres: localization and plasticity. Neuroscience 20:739-748.

Sakimura K, Morita T, Kushiya E, Mishina M (1992) Primary structure and expression of the $\gamma 2$ subunit of the glutamate receptor channel selective for kainate. Neuron $8: 267-274$.

Schlaggar BL, Fox K, O'Leary DDM (1993) Postsynaptic control of plasticity in developing somatosensory cortex. Nature 364:623-626.

Seeburg PH (1993) The molecular biology of mammalian glutamate receptor channels. Trends Neurosci 16:359-365.

Sommer B, Köhler M, Sprengel R, Seeburg PH (1991) RNA editing in brain controls a determinant of ion flow in glutamate-gated channels. Cell 67:11-19.

Sommer B, Burnashev N, Verdoorn TA, Kainänan K, Sakmann B, Seeburg PH (1992) A glutamate receptor channel with high affinity for domoate and kainate. EMBO J 11:1651-1656.

Stanfield BB, Cowan WM (1988) The development of the hippocampal region. In: Cerebral cortex, Vol 7, Development and maturation of cerebral cortex (Peters A, Jones E, eds), pp 91-126. London: Plenum.

Tsumoto T, Hagihara K, Sato H, Hata Y (1987) NMDA receptors in the visual cortex of young kittens are more effective than those of adult cats. Nature 327:513-514.
Ultsch A, Schuster CM, Laube B, Schloss P, Schmitt B, Betz H (1992) Glutamate receptors of Drosophila melanogaster: cloning of a kainateselective subunit expressed in the central nervous system. Proc Natl Acad Sci USA 89:10484-10488.

Unnerstall JR, Wamsley JK (1983) Autoradiographic localization of high-affinity $\left[{ }^{3} \mathrm{H}\right]$ kainic acid binding sites in the rat forebrain. Eur $\mathrm{J}$ Pharmacol 86:361-371.

Vickers JC, Huntley GW, Edwards AM, Moran T, Rogers SW, Heinemann SF, Morrison JH (1993) Quantitative localization of AMPA/ kainate and kainate glutamate receptor subunit immunoreactivity in neurochemically identified subpopulations of neurons in the prefrontal cortex of the macaque monkey. J Neurosci 13:2982-2992.

Wang L-Y, Taverna FA, Huang X-P, MacDonald JF, Hampson DR (1993) Phosphorylation and modulation of a kainate receptor (GluR6) by cAMP-dependent protein kinase. Science 259:1173-1175.

Watanabe M, Inoue Y, Sakimura K, Mishina M (1992) Developmental changes in distribution of NMDA receptor channel subunit mRNAs. Neuroreport 3:1138-1140.

Wenthold RJ, Petralia RS, Zhu W-S (1993) Subunit-specific antibodies to study the structure and distribution of glutamate receptors. J Neurochem [Suppl] 61:S123B.

Werner P, Voigt M, Kainänan K, Wisden W, Seeburg PH (1991) Cloning of a putative high-affinity kainate receptor expressed predominantly in hippocampal CA3 cells. Nature 351:742-744.

Wisden W, Morris BJ (1994) In situ hybridization with synthetic oligonucleotide probes. In: In situ hybridization protocols for the brain (Wisden W, Morris BJ, eds), in press. London: Academic.

Wisden W, Seeburg PH (1993a) Mammalian ionotropic glutamate receptors. Curr Opin Neurobiol 3:291-298.

Wisden W, Seeburg PH (1993b) A complex mosaic of high-affinity kainate receptors in rat brain. J Neurosci 13:3582-3598.

Young AB, Fagg GE (1990) Excitatory amino acid receptors in the brain: membrane binding and receptor autoradiographic approaches. Trends Pharmacol Sci 11:126-133. 